Article

\title{
Sustainable Waste Management for a City Multifloor Manufacturing Cluster: A Framework for Designing a Smart Supply Chain
}

\author{
Tygran Dzhuguryan (1) and Agnieszka Deja *(1)
}

check for updates

Citation: Dzhuguryan, T.; Deja, A. Sustainable Waste Management for a City Multifloor Manufacturing Cluster: A Framework for Designing a Smart Supply Chain. Sustainability 2021, 13, 1540. https://doi.org/ $10.3390 /$ su13031540

Academic Editors: Lenka Ližbetinová, Eva Nedeliaková and Miloš Hitka Received: 30 December 2020

Accepted: 25 January 2021

Published: 1 February 2021

Publisher's Note: MDPI stays neutral with regard to jurisdictional claims in published maps and institutional affiliations.

Copyright: (C) 2021 by the authors. Licensee MDPI, Basel, Switzerland. This article is an open access article distributed under the terms and conditions of the Creative Commons Attribution (CC BY) license (https:/ / creativecommons.org/licenses/by/ $4.0 /)$.
Faculty of Engineering and Economics of Transport, Maritime University of Szczecin, Wały Chrobrego 1-2, 70-500 Szczecin, Poland; t.dzhuguryan@am.szczecin.pl

* Correspondence: a.deja@am.szczecin.pl; Tel.: +48-914-809-650

\begin{abstract}
This study focuses on integrated sustainable waste management (ISWM) within a city multifloor manufacturing (MFM) cluster. Manufacturing activities in residential areas of the urban environment and the associated generation of municipal production waste (MPW) are serious problems. The primary goal of this study is to design smart supply chain (SSC) scenarios for the shipment of MPW from a city MFM cluster under uncertainty. This paper presents a new model of the finite MPW generation capacity for a city MFM cluster on the basis of an analysis of its finite production capacity using the material flow analysis (MFA) methodology. The proposed model allows us to determine the number of transport fleet units needed for the implementation of various supply chain (SC) scenarios of MPW. To select the best scenario for MPW shipment in real time, the application of SSC and SSC management (SSCM) technologies is proposed. SSCM performance indicators are proposed which allow us to evaluate the efficiency of using vehicles for cluster MPW transportation. The numerical values of the SSCM performance indicators for various options regarding the handling of city MFM buildings using trucks are obtained. These evaluations form the basis for the decision-making and planning associated with the SSCs of MPW.
\end{abstract}

Keywords: multifloor manufacturing; finite production capacity; production waste; closed-loop recycling; sustainable waste management; smart supply chain; blockchain technology; transport

\section{Introduction}

One of the priorities in global sustainable development is the reduction in harmful atmospheric emissions due to the unjustified international and intercontinental cargo transportation of consumer goods from the producer to consumer [1]. Such cargo transportation is justified only in cases when it is impossible to produce household goods directly at the places of consumption due to the climatic or natural characteristics of the producing countries [2,3]. Reducing the distance between the producer and consumer contributes not only to environmental sustainability, but also to the sustainable territorial development of the regions and cities of various countries, which is manifested in economic (employment of the population and enhancement of their well-being, the development of small and medium enterprises, etc.) and social terms (development of education, new production and educational relations, improvement of the culture of production, growth of interpersonal communications, etc.) [4,5].

The placement of household goods manufacturers directly in the residential part of a city allows the needs of the customer to be quickly met. The Smart City Initiative and the concepts of Industry 4.0 (I4.0), Internet of Things (IoT), Internet of Services, and Social Manufacturing are aimed at the sustainable development of regions and huge cities [4,6-15] and the formation of city multifloor manufacturing (MFM) clusters and mega clusters [5], which are designed to preserve the quality of life of citizens. The sustainable development of City Manufacturing 4.0 (CM4.0) in the framework of the I4.0 paradigm is based on: 
- the placement of industrial production, industrial, and technological parks outside of the residential areas of the city $[16,17]$;

- the use of modern information and environmentally friendly production technologies and modular lightweight technological equipment, changing the quality of labor resources in the conditions of continuous self-learning [4,6,18-21];

- the use of sustainable supply chains (SCs), closed-loop SC networks, and reverse logistics in the framework of the circular economy and sustainable freight transport systems [15,22-28];

- the creation of city Advanced Technology and Education Parks (ATEPs), providing not only educational services, but also innovative products and manufacturing technologies for various enterprises within the framework of regional and/or international cooperation with a wide range of stakeholders [6,28];

- the municipal policy for the sustainable development of CM4.0 and distributed zones of urban entrepreneurship, aimed at creating favorable tax conditions and infrastructure incentives to attract investment and private companies [29].

This paper focuses on the integrated sustainable waste management (ISWM) within a city MFM cluster and is based on analysis scenarios of the smart supply chain (SSC) of municipal production waste (MPW), considering the capacity of its generation. In urban conditions, such waste can be classified as municipal nonproduction waste (MNPW) and MPW, which are removed from the cluster territory in accordance with the principle of the separate formation of their SCs $[21,30]$.

The remainder of this paper is organized as follows. Section 2 presents the literature review of the research on sustainable waste management for city MFM. Section 3 provides the methodology employed in our research. Section 4 presents the problem definition, notation, and assumptions. The proposed finite capacity of the MPW generation model for a city MFM cluster, scenarios of SSC and SSC management (SSCM) technologies for MPW shipment from the cluster's enterprises, and a case study are elaborated in Section 5. Section 6 contains a discussion of the results obtained and available SSC solutions. Finally, conclusions and opportunities for future research are given in Section 7.

\section{Literature Review}

\subsection{City MFM Cluster and Transport}

A city MFM cluster is a group of MFM and nonmanufacturing buildings and their City Logistics Node (CLN) in a dedicated residential area of a huge city, designed to produce household goods and provide services to the population and enterprises of the cluster, city, and agglomeration. The integration of CLNs that are located close to one another in the city logistics cluster contributes to the formation of a city MFM mega cluster [5]. A city MFM cluster contains mainly small- and medium-sized enterprises of various categories of production activity, which has a positive impact on the development of business competition and the network form of production organization [31].

The material flows for a city MFM cluster's enterprises are realized by an innovative transport unit, called Intelligent Reconfigurable Trolleys (IRTs), which enable the enterprises [28,32,33]:

- to carry out their reconfiguration, taking into account the requirements for transportation and storage of a wide range of industrial goods (materials, workpieces, components and complete products, finished products and goods, materials and components for the assembly, operation, repair and disposal of technological equipment, etc.), including multi-IRT for road transport or containers;

- to use both transportation within the cluster (cranes, freight elevators and light or e-trucks, rail, marine and air transport, cranes, freight elevators, and trucks) and multimodal and intermodal transportation (containers, trucks, rail, marine, and air transport);

- to carry out the certification, identification, and monitoring of IRTs in real time due to the presence of an appropriate recording device (token) for SSC management (SSCM) 
realization [34] using connectivity based on the Manufacturing 4.0 principles of IoT, radio-frequency identification (RFID), LoRa (long range), etc. [35,36].

IRTs are the main unit of a city MFM cluster's freight transport system, which includes freight elevators of production buildings, light or e-trucks, etc. The sustainability of a freight transport system is ensured by the choice of appropriate vehicles and an SSCM that aims to reduce order lead times, while minimizing empty runs and "unutilized" space/weight in IRTs, freight elevators, and light or e-trucks [4,24,37].

\subsection{Municipal Waste Management within a City MFM Cluster}

Municipal nonproduction waste (MNPW) is generated within a city MFM cluster by its population, nonproduction organizations (logistics node, banks, restaurants, shops, schools, universities, sports centers, clinics, etc.), and the personnel of manufacturing enterprises, as a result of cleaning the territory and trimming green spaces. The MNPW collections are sorted and shipped by the population, the employees of manufacturing enterprises, and the cleaners of the cluster to stationary solid waste containers, as well as to stationary and mobile selective waste collection points. The stationary solid waste containers are located outside the MFM buildings on specially designated areas of the cluster and have five colors, each of which defines only one category of waste collection: the blue container is for paper, the yellow is for metal and plastic, the green is for glass, the brown is for BIO waste, and the black is for other mixed waste. The stationary and mobile selective waste collection points are also located on the territory of the cluster (the stationary selective waste collection points can also be located outside of the cluster) and are designed to collect a certain category of MNPW: expired medicines; bulky waste (including furniture); green waste; construction, restoration, and demolition waste (including debris); used tires, electrical and electronic equipment, and batteries and accumulators. The waste delivery to these points is carried out by the population and organizations independently. The MNPW is removed to municipal waste transfer stations (WTSs) from stationary solid waste containers every day at a scheduled time, and from stationary and mobile selective waste collection points only after they are filled. In the first case, a specialized truck is used for the MNPW removal for each selective collection, and in the second case, municipal WTS trucks are used [21,38-44]. It should be emphasized that municipal WTSs also receive waste generated at various urban facilities outside of the city MFM clusters [21,38,44-46]. After processing the MNPWs in municipal WTSs, they are delivered to the WTSs of a Recycling, Treatment, and Energy Park (RTEP) for final processing according to their compositions, material hierarchy, and desired output functions [47,48].

The MPW is generated, collected, sorted, and shipped by the production enterprises of the city MFM cluster. The MPW also includes technological equipment, their individual modular units, materials, and liquids that have run out of service life and are subject to disposal. For MPW transportation via IRTs, freight elevators, trucks, and a CLN are used. The transportation of IRTs holding MPW in light or e-trucks can be carried out together with other IRTs in the form of interconnected multi-IRT, which can be used as a city container $[21,32,33]$. However, it is not always possible to furnish a city container with compatible freights, deliver it to the CLN, and after performing unloading-loading operations, deliver the homogeneous city container with MPW to the WTS under supply uncertainty. Therefore, it is necessary to consider the features of sustainable SC management (SCM) and the SSCM of MFM.

\subsection{Sustainable SCM and the SSCM of MPW}

The need to optimize SC chains within huge cities is associated with stringent requirements relating to sustainable development, as well as the intensity of urban traffic. The sustainability of production in a city is also determined by the sustainability of the SCM in the city, just as the finite production capacity of the city MFM cluster also depends on the SC performance. The conceptual approach of sustainable SCM is narrowly understood as ensuring the delivery of environmentally friendly materials and products in a circular 
economy using sustainable transport systems $[24,49,50]$. In a broader sense, the fundamental principles of sustainable SSM are a holistic and interdisciplinary three-dimensional approach to the various stages of SCs in terms of the established Triple Bottom Line (TBL) evaluation criteria, which emphasize the need to use indicators that consider the environmental, economic, and social aspects of sustainability [49-51]. Sánchez-Flores et al. [49] defined SSCM as "the preservation of the balance that may exist between social responsibility, care for the environment, and economic feasibility throughout the supply chain functions". The implementation of the concept of sustainable SCM is linked to the development of appropriate tools to monitor SC performance towards sustainability [51]. Various models of sustainable SCM can be used as practical tools to assess its performance over time in terms of both the three-dimensional approach (TBL) [50-52] and its individual aspects $[26,27,53-55]$. These models can be used both to assess the sustainability of SCM within a city MFM cluster based on the TBL criteria, and more narrowly focused criteria that characterize certain aspects of the sustainable development of the cluster. It is recognized that it is difficult to assess sustainability in the framework of the threedimensional SCM approach [51]. Therefore, most research is devoted to data collection, the development of indicators, and reporting certain aspects of SCM sustainability, such as those related, for example, to minimizing the harmful effects of transport activities on the environment [24,26,28].

In the framework of a city MFM cluster, it is advisable to focus on SCM sustainability indicators that allow us to assess the sustainability of processes under supply uncertainty: the capacity of freight transport, its empty runs and gas emissions, the organization of environmentally friendly transport infrastructure, etc. [24,26,28,50]. The implementation of sustainable SCM is carried out in consideration of information about the manufacturing structure of suppliers and consumers, energy and resource flows, human factors, learning and social aspects, symbiosis, and spatial context using information and communications technology (ICT) and cyber-physical systems (CPSs) [26,53-55]. The key sources of information for the implementation of sustainable SCM within a city MFM cluster are devices for identifying and monitoring IRT content and traffic, which are installed in each IRT to record and transmit the necessary information in real time using a wireless local area network $[28,31,33]$. Access to the local network is achieved by installing the appropriate equipment in the manufacturing buildings, CLN, and trucks $[28,33]$.

SSCM means delivering/receiving the correct item in the correct volume at the correct time and the correct place for the correct price in the correct condition to the correct customer using information technologies for the intellectualization, digitalization, networking, and automation of the SSC [56-59]. The SSC is a modern and interconnected system, which expands from separated, regional, and single firm applications to the wide and systematic implementation of SCs. It is characterized by the use of interconnections for shared decision-making in the end-to-end SC, machine intelligence, instrumentation, automation, integration, and innovation [58-60].

SSCM technologies are aimed at building sequences of actions that agree with the properties of the process and specific goal of the management, with the ability to assess situations and solve problems at various levels and combine nine new technologies, including big data analytics, machine learning, drones, the IoT, advanced robotics, the sharing economy, cloud computing, modular lightweight technological equipment for sustainable manufacturing, and blockchains $[10,58,59,61]$.

SSCM is the link between smart manufacturing and smart cities and cannot be implemented outside of this common economic, information, and cyber-physical space. SSCM is the most important tool for cooperation between partners in the SCs, allowing for decisionmaking based on objective information received automatically from various monitoring and diagnostic systems [60]. The main focus in the SSCM is the exchange of information between partners, aimed at operational improvements, the mitigation of information blocking, transparency of cooperation in the SCs, and increases in risk management under supply uncertainty [56]. The development of blockchain technology contributes to the 
improvement of the reliability of the information and transparency of the SC, simplifying the involvement of suppliers. Blockchain technology is a common and highly effective tool for sustainable SCM and SSCM [62]. Thus, the ability of smart systems to provide increased SC sustainability, in terms of the procurement, manufacturing, inventory management, trading, information sharing and automation, supply transparency, skill and capability development, is evident $[55,60,63,64]$. Considering the interrelation of these supply management systems, some general aspects of ISWM within a city MFM cluster related to the selection of the best scenarios for MPW shipment are considered in this paper, with the intention of minimizing the harmful impact of transport activities on the environment [26] by reducing empty runs of vehicles and the use of SSCM technology.

\section{Methodology of Research}

The methodological basis for waste management in the framework of a city MFM cluster is the ISWM theory, which has three key components: (1) waste management stakeholders, (2) components of the waste management system, and (3) the technical, environmental, legal, and other aspects [21,65].

The waste management stakeholders, based on established restrictions imposed by various aspects of the third key component of ISWM theory, ensure:

- decision-making regarding the use of sustainable production and transportation technology within the cluster in terms of technical, environmental, legal, and other aspects [65-68];

- compliance with safe waste management requirements, considering their type and hazard rating for the environment and human health $[21,44,65,69]$.

The second key component of ISWM is the aspects of the waste management system associated with its generation and separation, collection, transfer and transportation, processing, and disposal [65]. This component of the waste management system in a developed infrastructure of a megalopolis (Figure 1) is the most significant due to the intensity of urban traffic flows and uncertainty in supply.

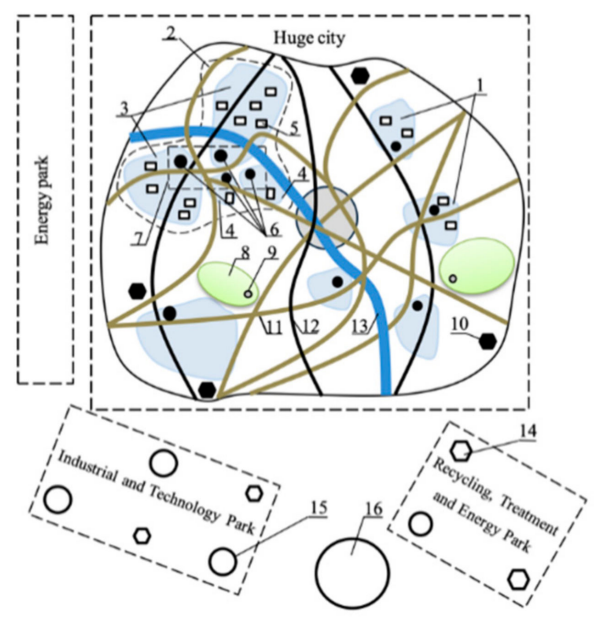

Figure 1. City multifloor manufacturing (MFM) clusters and mega cluster in the structure of a megapolis: 1—city MFM cluster; 2-city MFM mega cluster; 3 -median city MFM cluster; 4-small city MFM cluster; 5-city MFM building; 6-City Logistics Node (CLN); 7-city logistics cluster; 8-Advanced Technology and Education Park (ATEP); 9-logistics node for ATEP; 10-municipal waste transfer station (WTS); 11, 12 and 13-road, railway, and river transport; 14-WTS of the Recycling, Treatment, and Energy Park (RTEP); 15-industrial and technology park; 16-logistics hub [28].

The presence in the metropolis of a huge city with various sizes of MFM clusters, ATEPs, municipal Waste Transfer Stations (WTSs), and RTEP with WTSs, etc., determines the need to improve the MPW management system using SSC technology $[20,21,24,28]$. 
The development of a model of MPW generation is based on the material methodology and capacity requirements planning (CRP) [70] of the enterprises on each production floor of the MFM building, taking into account the fundamental principle of material flow analysis (MFA), i.e., material balance: the inflow to the MFA system is equal to the outflow [71-73] and throughput of freight elevators (Figure 2), and the method of calculation of the actual waste generation [21].

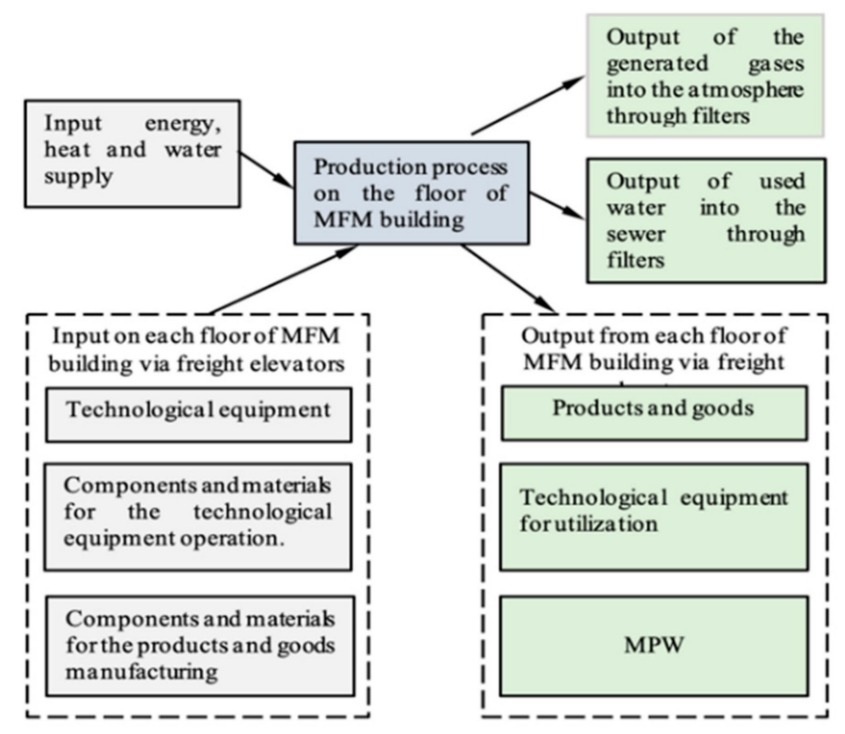

Figure 2. Application of the material balance principle for the production floor of a city MFM building.

Figure 3 shows the structure of the SCs of MPW for a city MFM cluster, as part of the implementation of the circulation economy in a metropolis.

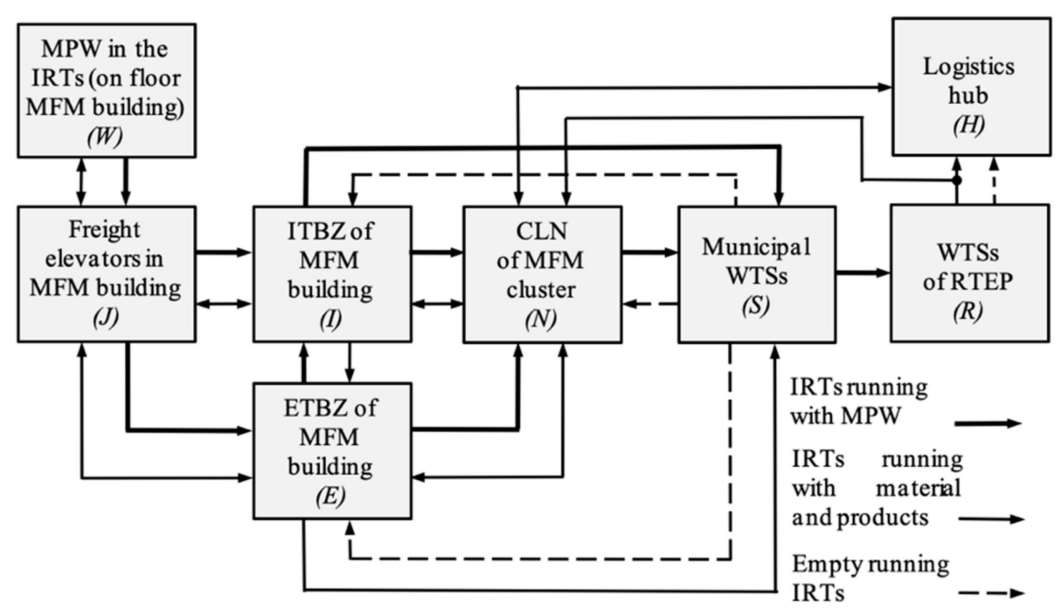

Figure 3. The structure of the supply chains (SCs) of municipal production waste (MPW) for a city MFM cluster in the framework of a megapolis.

The key means of transport for such deliveries are IRTs, which are used at almost all stages of the following process:

1. generation, sorting, and collection of MPW in IRTs (on an MFM building floor);

2. vertical transport (freight elevator in the MFM building);

3. consolidation and segregation (internal transfer and buffer zones (ITBZs) and/or external transfer and buffer zones (ETBZs);

4. transport of city MFM cluster (between MFM buildings and CLN); 
5. transport of municipal WTS enterprises (between MFM buildings and municipal WTSs and/or between CLN and municipal WTSs);

6. unloading of the IRTs with the MPW in the municipal WTSs, washing and disinfection of the empty IRTs, and their partial targeted shipment to production enterprises of the city MFM cluster;

7. MPW handling and packaging in the municipal WTSs, with their subsequent shipment to the WTSs of the RTEP, including by means of IRTs;

8. transport of municipal WTSs and/or WTSs of the RTEP (between municipal WTSs and WTSs of the RTEP);

9. unloading of the IRTs with the MPW in the WTSs of the RTEP, washing and disinfection of the empty IRTs, and their partial targeted shipment to a logistics hub;

10. processing (recycling, etc.) of the MPW in the RTEP, with the subsequent shipment of material to the logistics hub or CLN, including by means of IRTs;

11. transport of municipal WTSs and/or WTSs of the RTEP (between the WTSs of the RTEP and logistics hub or CLN).

One of the key stages of the SCs of MPW for a city MFM cluster is the third stage. The realization of the third stage of the SCs of MPW for the city MFM cluster is most effective when using the ITBZ for performing the multi-IRT consolidation or segregation and loading and unloading (Figure 4). The ITBZ is located on the ground floor of the MFM building and must have the necessary dimensions and space for loading and unloading operations and places for light or e-trucks to enter. In cases where light or e-trucks cannot easily access the MFM building, ETBZ is used for these operations. ETBZ is also used for combined the execution of these operations in cases of insufficient ITBZ sizes or emergency and other unforeseen situations.

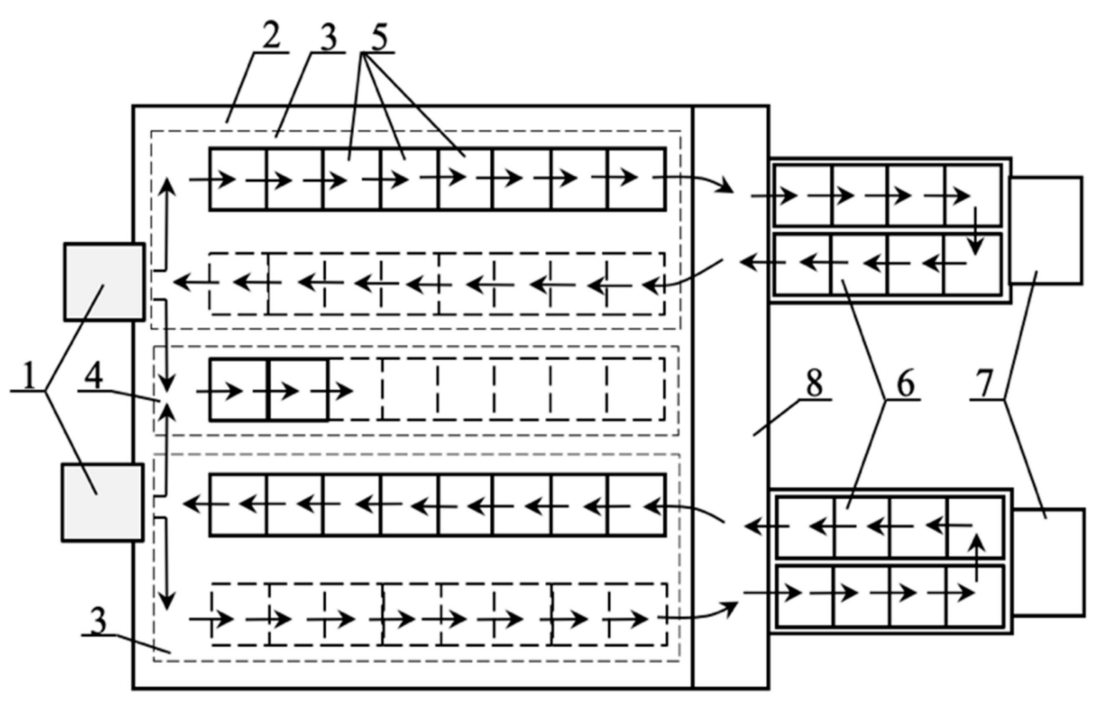

Figure 4. Spatial plan of loading and unloading operations on the ground floor (internal transfer and buffer zone-ITBZ) with two freight elevators of a city MFM cluster's building: 1-freight elevators, 2-ground floor area for the picking operations of multi-Intelligent Reconfigurable Trolley (IRTs); 3-transfer zone of the ground floor area, 4-buffer zone of the ground floor area, 5-IRTs, 6-multi-IRTs, 7-light or e-trucks, and 8-overpass [28].

The features of the first two stages of the SCs of MPW for a city MFM cluster are:

1. the possibility of the full or quasi-full handling of a building floor if the only ITBZ is used at the third stage, which includes the delivery of an empty IRT by a freight elevator from the ground floor and the shipment of the MPW-filled IRT to the ground floor. This eliminates empty runs of freight elevators in MFM buildings [28];

2. the possibility of the partial or quasi-full handling of a building floor if the only ETBZ is used at the third stage. The partial handling of the building's floors by freight 
elevators occurs when a freight elevator is sent a full load of IRT (IRTs) in only one direction. To reduce empty runs of freight elevators, the quasi-full handling of the building's floors is used, instead of their partial handling. The quasi-full handling of the building's floors by freight elevators is when the freight elevator is sent or returned to the ground floor of the building with fully loaded IRTs, and only their partial handling is carried out on the building floors [28];

3. the use of additional buffer IRTs for MPW collection on the MFM building floors. This need arises when, for one reason or another, it is not possible to ship the IRTs filled with MPW in a timely manner. Buffered IRTs are used if there is the possibility of shortterm and safe storage of the MPW in IRTs on the building's floors, without harmful consequences for the personnel of the production enterprises, the environment, or the state of MPW.

In the framework of a city MFM cluster, the scenarios of SSC and SSCM technology of a MPW shipment is extended to the first nine stages of MPW transportation, while the possible scenarios of the MPW transportation are considered only in the 3rd-9th stages.

The following part will present the problem definition, notation, and assumptions.

\section{Problem Definition, Notation, and Assumptions}

\subsection{Problem Definition}

The simplest scenario of MPW shipment is to fill a city container with only MPW for its delivery to the municipal WTS. However, such a scenario is quite difficult to implement due to the different intensity of generation and the perishability factor. Therefore, the main scenario for MPW shipment is to fill a prefabricated city container, considering the compatibility of freights, and deliver it to the CLN, where, after its disassembly and sorting, a homogeneous city container is filled with MPW for delivery to the municipal WTS [21]. It is obvious that such a scenario of MPW shipment under uncertainty in SC is not always acceptable and can lead to an overload of the CLN operation. In this respect, there is a need to consider more efficient scenarios for the shipment of waste, bearing in mind the determination of the final capacity of generation, the required number of vehicles, and the possibility to make this process more sustainable and smarter.

Figure 4 presents the flow diagram of the sustainable SC of MPW for a city MFM cluster used in this study.

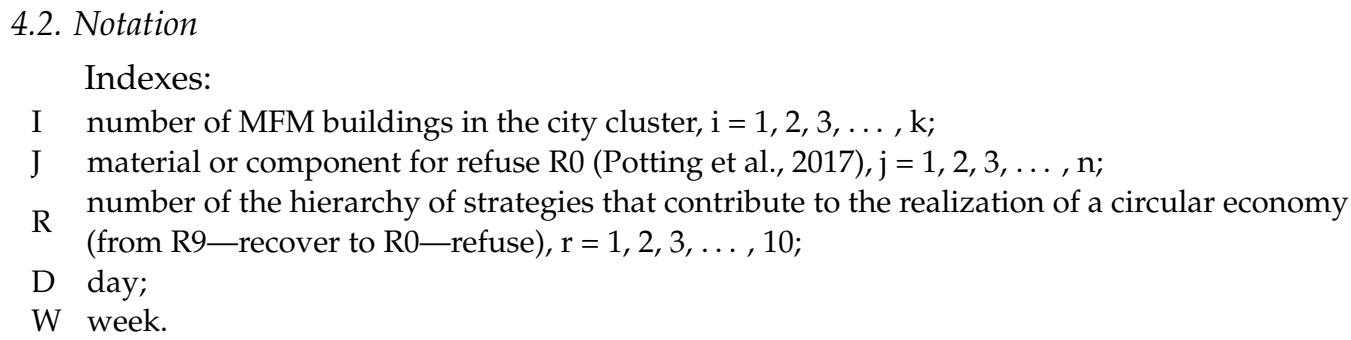


$\mathrm{f}_{\mathrm{i}} \quad$ interfloor distance of item $\mathrm{i}(\mathrm{m})$;

$L_{i} \quad$ distance between the ITBZ (ETBZ) of item $i$ and the CLN of the cluster $(\mathrm{km})$;

$L_{T . i .3-6}$ distance between the ITBZ (ETBZ) of item i and the municipal WTS (km);

$\varepsilon_{\text {.i }} \quad$ number of freight elevators of item $\mathrm{i}$ (unit);

$\mathrm{T}_{\mathrm{R} . \mathrm{i}} \quad$ freight elevator round trip time of item $\mathrm{i}(\mathrm{h})$;

$\mathrm{T}_{T, i 1(2)}$ round trip of the light or e-truck between the i-th MFM building and the CLN of the

cluster (h);

$T_{\text {T.i.3-6 }}$ round trip time of the truck between the i-th MFM building and the municipal WTS (h);

$\mathrm{M}_{\mathrm{R} . \mathrm{i}} \quad$ time indicator for the freight elevator operation of item $\mathrm{i}(\mathrm{h})$;

$t_{\text {E.i }} \quad$ IRT loading/unloading time of item i (s);

$t_{\text {f.i }} \quad$ single floor flight time, representing the time of acceleration and deceleration of item (s);

$t_{0 . i} \quad$ the door opening time of item $\mathrm{i}(\mathrm{s})$;

$t_{c . i} \quad$ the door closing time of item i (s);

$t_{m p . i}$ the time of the multi-IRT picking operations in the ground floor area of item $i(s)$;

$\mathrm{F}_{\mathrm{i}} \quad$ number if floors of the manufacturing part of item $\mathrm{i}$;

$\lambda_{\mathrm{E} . \mathrm{i}} \quad$ number of the IRTs in the freight elevator of item i (unit);

$\mathrm{k}_{\mathrm{C} . \mathrm{i}} \quad$ coefficient of operation time cycle losses for the freight elevators of item $\mathrm{i}$;

$\mathrm{K}_{\mathrm{EF} . \mathrm{i}} \quad$ coefficient of the freight elevator occupancy rate of item i;

$\mathrm{K}_{\mathrm{E} . \mathrm{i}} \quad$ coefficient taking into account the average weekly downtime of freight elevators falling

within their round trip time of item $\mathrm{i}$;

$\mathrm{N}_{\mathrm{j}} \quad$ average MPW generation rates of item $\mathrm{j}$;

$N_{T 1(2)}$ number of the light or e-trucks fir the city MFM cluster in the case of using the first and second scenarios of SSC (unit);

number of IRTs for the city MFM cluster in the case of using the first and second

$\lambda_{1(2)} \quad$ number of IRTs for the city

$\lambda_{\mathrm{T} . \mathrm{i}} \quad$ number of IRTs in the light or e-truck for servicing item i (unit);

$t_{T . i} \quad$ IRT loading/unloading time for the light or e-truck of item i (s);

$K_{\lambda . i} \quad$ coefficient of the IRTs using item i;

$K_{T F . i} \quad$ coefficient of the e-truck occupancy rate of item i;

$K_{T i} \quad$ coefficient taking into account the average weekly downtime of the light or e-truck falling within their round trip time of item i;

$N_{T .3-6}$ number of trucks for the city MFM cluster in the case of using the first and second

scenarios of SSC (unit);

$\lambda_{3-6} \quad$ number of IRTs for the city MFM cluster in the case of using the first and second

scenarios of SSC (unit);

$\lambda_{T} \quad$ number of IRTs in the truck for servicing the city MFM cluster (unit);

coefficient that determines the increase in distance between the ITBZ (ETBZ) of the i-th

$k_{\text {T.i.3-6 }} \quad$ MFM building and the municipal WTS due to the intracluster servies of MFM buildings (for scenarios 3 and 4 the coefficient $k_{T . i .3-4}$ );

$t_{T . i} \quad$ IRT loading/unloading time for the truck of item i (s);

$K_{\lambda . i} \quad$ coefficient of the IRTs using item $i$;

$K_{T F . i} \quad$ coefficient of the truck occupancy rate of item i;

$K_{T . i} \quad$ coefficient taking into account the average weekly down time of the trucks falling within their round trip time of item i;

SSCM performance indicator based on an estimate of the utilization rate of cases of the

$E_{H F . d(w)}$ full handling of the city MFM cluster's buildings during a predetermined time period of item $\mathrm{d}(\mathrm{w})$;

SSCM performance indicator based on an estimate of the utilization rate of cases of the

$E_{H . d(w)}$ full, quasi-full, and partial handling of the city MFM cluster's buildings during a predetermined time period of item $\mathrm{d}(\mathrm{w})$;

$J_{H F . d(w)}$ number of cases of the full handling of the i-th building of the city MFM cluster during

$J_{H F . d(w)}$ a predetermined time period of item $\mathrm{d}(\mathrm{w})$;

$J_{H Q d(u)}$ number of cases of the quasi-full handling of the i-th building of the city MFM cluster

$\int_{H Q . d(w)}$ during a predetermined time period of item $\mathrm{d}(\mathrm{w})$;

$J_{H P}$ number of cases of the partial handling of the i-th building of the city MFM cluster

$J_{H P . d(w)}$ during a predetermined time period of item $\mathrm{d}(\mathrm{w})$.

\subsection{Assumptions}

The following assumptions are considered in this model: 
1. the finite capacity on each production floor of the MFM buildings of the city cluster is the same [74];

2. the production capacity for each floor is directly proportional to the production area and depends on the parameter $\mathrm{q}_{\mathrm{i}}$ :

$$
\mathrm{C}_{\mathrm{f} . \mathrm{i}}=\mathrm{q}_{\mathrm{i}} \mathrm{S}_{\mathrm{C} . \mathrm{i}} \text {. }
$$

3. the production capacity on each floor of the MFM building is determined by the number of freight elevators in the MFM building and their throughput [28]. The inputoutput balance material (see Figure 2) on the production floor of the MFM building via freight elevators and technical characteristics of the MFM building and their freight elevators, including a condition of constancy of the MFM building's area on each of its floors and their distribution, are defined by the following equations $[28,66]$ :

$$
\begin{gathered}
\mathrm{T}_{\mathrm{R} . \mathrm{i}} \mathrm{C}_{\mathrm{f} . \mathrm{i}}=\varepsilon_{\mathrm{i}} \mathrm{Q}_{\mathrm{E} . \mathrm{i}}=\varepsilon_{\mathrm{i}} \mathrm{C}_{\mathrm{E} . \mathrm{i}} \mathrm{M}_{\mathrm{R} . \mathrm{i}} ; \\
\varepsilon_{\mathrm{i}} \mathrm{S}_{\mathrm{E} . \mathrm{i}}=\mathrm{S}_{\mathrm{i}}-\mathrm{S}_{\mathrm{C} . \mathrm{i}} ;
\end{gathered}
$$

where

$$
\begin{gathered}
\mathrm{T}_{R . \mathrm{i}}=\mathrm{M}_{\mathrm{R} . \mathrm{i}} \mathrm{F}_{\mathrm{i}}\left(\mathrm{F}_{\mathrm{i}}+1\right) ; \\
\mathrm{M}_{\mathrm{R} . \mathrm{i}}=\frac{\mathrm{K}_{\mathrm{C} . \mathrm{i}} \mathrm{f}_{\mathrm{i}}}{3600 \mathrm{~K}_{\mathrm{EF} . \mathrm{i}} \mathrm{K}_{\mathrm{Ei}} \mathrm{v}_{\mathrm{E} . \mathrm{i}}} ; \\
\mathrm{K}_{\mathrm{C} . \mathrm{i}}=1+\frac{\mathrm{v}_{\mathrm{E} . \mathrm{i}}\left[4 \lambda_{\mathrm{E} . \mathrm{i}} \mathrm{t}_{\mathrm{E} . \mathrm{i}}+2\left(2 \mathrm{t}_{\mathrm{f} . \mathrm{i}}+\mathrm{t}_{\mathrm{o} . \mathrm{i}}+\mathrm{t}_{\mathrm{c} . \mathrm{i}} \mathrm{t}_{\mathrm{mp} . \mathrm{i}}\right)\right]}{\mathrm{f}_{\mathrm{i}}\left(1+\mathrm{F}_{\mathrm{i}}\right)} .
\end{gathered}
$$

The following section will present possible SSC scenarios for the shipment of MPW by IRTs from a city MFM cluster, a model of the finite MPW generation capacity and transportation, SSCM technologies for the MPW shipment, and a case study.

\section{Results}

\subsection{Scenarios of SSC for the Shipment of MPW from a City MFM Cluster's Enterprises}

Figure 5 shows six possible SSC scenarios for the shipment of MPW by IRTs from a city MFM cluster's enterprises to the WTSs of a RTEP. Each of the proposed SSC scenarios for the MPW shipment can be used individually for the city MFM cluster's building, depending on the intensity of the MPW generation and its composition. In turn, the intensity of the MPW generation and its composition depends on the technologies and equipment used, their performance, as well as the current production plans of the enterprises of the city MFM cluster. These scenarios have advantages and disadvantages, which are manifested in various conditions of their application for the city MFM cluster. Given the uncertainty of supplies and the current changes in the intensity of the MPW generation in each individual production building of the city MFM cluster, it is necessary to determine which of the scenarios of SSC for the MPW shipment is the best in real time.

SSC scenario 1 for the MPW shipment is the most preferable compared with the other options due to:

- the versatility of its use for different production capacities and the generation of waste in the cluster within established limits, without the need to use buffer IRTs for waste collections;

- the division of the truck fleet into municipal WTSs and clusters, which expands the latter's ability to choose a sustainable transport fleet: light and/or e-trucks;

- the lack of IRT specialization for transported goods, which allows the IRTs with freights received by the enterprise to be used after unloading both for the transportation of manufactured products and goods and for generated waste;

- the joint transportation of MPW and other freights in light or e-trucks in the form of multi-IRTs, which simplifies the logistics and implementation of the SSC within the city MFM cluster;

- the lack of need for additional areas in the cluster territory to accommodate the ETBZ; 
- the reduction in the number of objects for service by trucks of the municipal WTSs or WTSs of RTEP, which, according to Little's law (1954), helps to reduce the lead time;

- the use of the freight elevators for the full handling or quasi-full handling of the production floor of the MFM building of the city cluster, which reduces empty runs and ensures continuity of the flow of materials, goods, and MPW in the framework of the circular economy concept and under supply uncertainty [28].

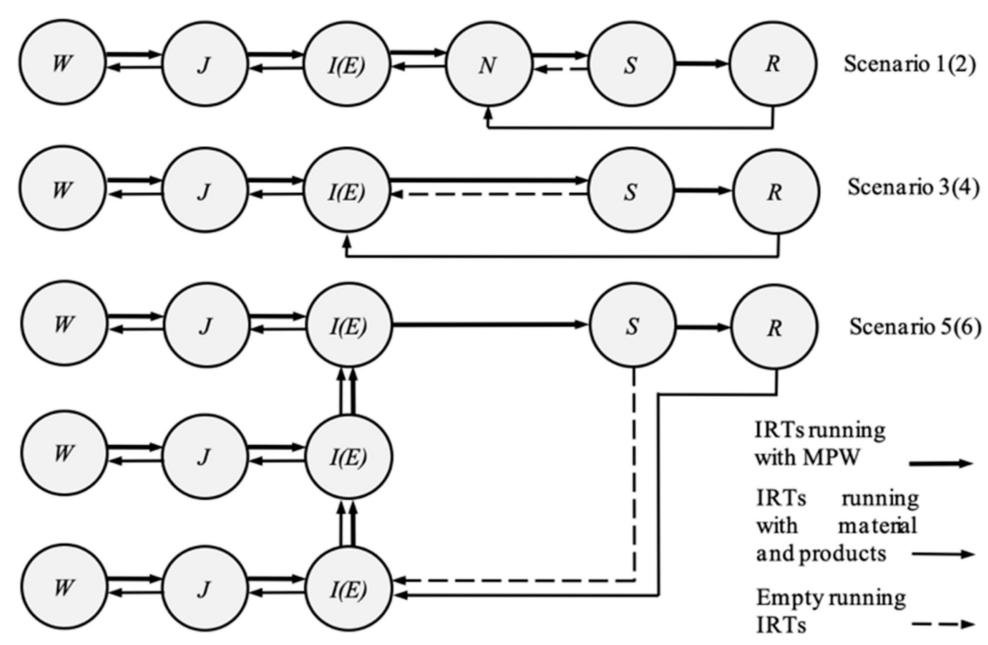

Figure 5. Smart supply chain (SSC) scenarios for the MPW shipment from the city MFM cluster's enterprises: $W$-the location of MPW generation in the city MFM cluster's building; J-freight elevator of the city MFM cluster's building; I-ITBZ of the city MFM cluster's building; E- external transfer and buffer zone (ETBZ) of the city MFM cluster's building; $N-C L N$ of the city MFM cluster; $S$-municipal WTSs; $R$-WTSs of RTEP.

This section may be divided into subheadings. It should provide a concise and precise description of the experimental results, their interpretation, as well as the experimental conclusions that can be drawn.

SSC scenario 2 for the MPW shipment is second in terms of preference compared to the other options. The SSC scenario 2 has almost the same advantages as SSC scenario 1 . The disadvantages of scenario 2 compared with scenario 1 include the need for additional areas in the cluster to accommodate the ETBZs, as well as the inability to use freight elevators for the full handling of the production floor of the MFM building of the city cluster [28]. A common disadvantage of scenarios 1 and 2 is the possibility for the CLN to be overloaded in the case of the city MFM cluster's operation with a finite production capacity.

SSC scenarios 1 and 2 are the most relevant to the MPW hipment from the city MFM cluster and allow us to implement the principle of the full handling of the cluster's production buildings. The full handling of the city MFM building is when the truck delivers to the ITBZ (ETBZ) and ships full sets of multi-IRTs from it, according to the truck's carrying capacity, while all the IRTs in these sets are completely filled with freights.

SSC scenarios 3-6 for the MPW shipment are auxiliary and are used in addition to the main scenarios 1 and 2 for unloading the CLN (scenarios 3 and 4) or transporting hazardous materials and the MPW [75,76], including perishable freights (scenarios 5 and 6), as well as in cases of the incomplete use of the cluster's production capacity. SSC scenarios 3-6 are implemented when the full set of multi-IRTs carrying MPW is accumulated or at a scheduled time using the trucks of the municipal WTSs or WTSs of RTEP. These scenarios have four options in terms of handling the production buildings of the cluster: full handling, quasi-full handling, not full handling, and mixed handling.

The definition of the full handling of an MFM building of a city cluster by trucks was presented earlier. The quasi-full handling of the MFM building is when the truck delivers to the CLN or municipal WTS the full set of multi-IRTs, which are completely filled with freights, and between the CLN and the ITBZ (ETBZ) of the MFM building, the truck delivers 
a full set of multi-IRTs, which are partially filled with freights or without freights. The transportation of an incomplete set of multi-IRTs or a complete set of multi-IRTs, which are partially filled with freights or without freights (except in cases of transportation according to quasi-full handling), is not considered as the full handling of the MFM building and is used for the emergency handling of the MFM building. Mixed handling of the city MFM building occurs when all three of the listed handling options are applied during a set time period, such as a calendar month.

Scenarios 3 and 4 of the MPW shipment are the best for cases where full handling of the MFM building is possible and when full sets of the multi-IRTs are available for the truck. In these cases, the implementation of scenarios 3 and 4 leads to the unloading of the CLN, a reduction in the number of trucks used, and loading and unloading operations.

Obviously, the choice of an SSC scenario for the MPW shipment is influenced by the MPW generation capacity in the cluster and, first, the finite capacity of the MPW generation and transportation for the city MFM cluster.

\subsection{Model of the Finite Capacity of the MPW Generation and Transportation for the City MFM Cluster}

The objectives of the suggested model are to determine the finite capacity of the MPW generation in the city MFM cluster in order to identify the need for vehicles and select sustainable scenarios for their shipment.

The input-output balance material (see Figure 2) is used to determine the production capacity for each floor of the i-th MFM building of the city cluster. The solutions of Equations (1)-(4) allow us to define the production capacity for each floor of the i-th MFM building of the city cluster:

$$
C_{f . i}=\frac{Q_{E . i}\left(S_{i}-C_{f . i} / q_{i}\right)}{T_{R . i} S_{E . i}}=\frac{Q_{E . i}\left(S_{i}-C_{f . i} / q_{i}\right)}{M_{R . i} F_{i}\left(F_{i}+1\right) S_{E . i}} ;
$$

After transformation, Equation (7) can be given as:

$$
C_{f . i}=\frac{Q_{E . i} S_{i}}{M_{R . i} F_{i}\left(F_{i}+1\right) S_{E . i}+Q_{E . i} / q_{i}},
$$

According to Equation (8), the total production capacity of the i-th MFM building of the city cluster with the Fi production floor can be given as:

$$
C_{i}=\frac{F_{i} Q_{E . i} S_{i}}{M_{R . i} F_{i}\left(F_{i}+1\right) S_{E . i}+Q_{E . i} / q_{i}} .
$$

The ratio of production and nonproduction areas (for freight elevators) on the floors is an important factor for the productive operation of the MFM building (Figure 6). Increasing the production area by reducing the number of freight elevators leads to the packing of products on the floors. In turn, reducing the production area of the floor by increasing the number of freight elevators leads to an increase in their capacity, but it reduces the production capacity of the enterprise. Obviously, you need to find the optimal area ratio for a given number of floors of the MFM building and the finite (limited) production capacity of the i-th MFM building (Figure 7) [67,74].

The search for the global maximum of the function Ci presented in Equation (9) is the goal of the mathematical optimization of the production operation on each floor of the i-th MFM building of the city cluster. This function is continuous and twice differentiable at the point $F(i(0))$. Then, under the condition:

$$
\mathrm{C}_{\mathrm{i}}^{\prime}\left(\mathrm{F}_{\mathrm{i}(0)}\right)=0,
$$

and

$$
\mathrm{C}_{\mathrm{i}}^{\prime \prime}\left(\mathrm{F}_{\mathrm{i}(0)}\right)<0,
$$


then $\mathrm{F}_{\mathrm{i}(0)}$ is the point of the local maximum.

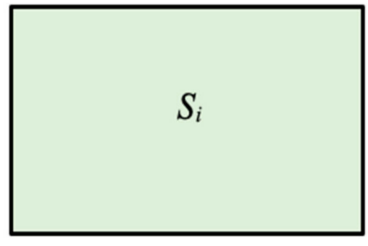

a)

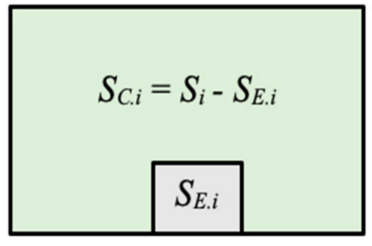

b)

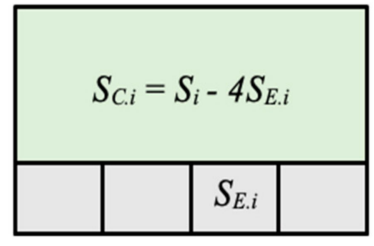

c)

Figure 6. Spatial plan of floor area of the i-th MFM building of the city cluster: (a)-one-floor manufacturing building without freight elevators; (b) - MFM building with a freight elevator; (c) MFM building with four freight elevators.

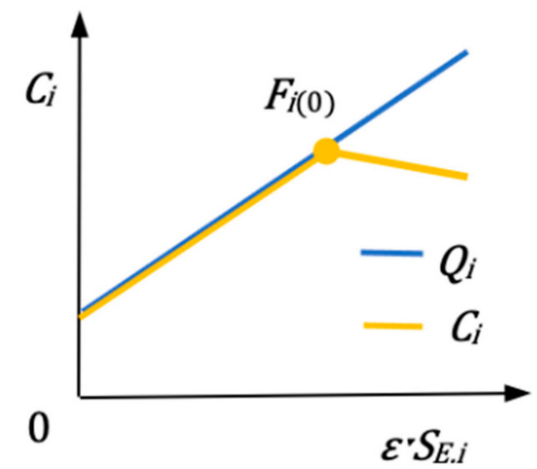

Figure 7. Dependence of the total production capacity and carrying capacity of the freight elevators of the i-th MFM building of the city cluster on the parameter $\varepsilon \cdot S_{E . i}$.

We can define the first condition for the function as:

$$
\frac{d}{d F_{i}} C_{i}=\frac{d}{d F_{i}}\left[\frac{Q_{E . i} F_{i} S_{i}}{M_{R . i} F_{i}\left(F_{i}+1\right) S_{E . i}+Q_{E . i} / q_{i}}\right]=0 .
$$

After its transformation, Equation (10) can be given as:

$$
\frac{d}{d F_{i}}\left[\frac{F_{i}}{a_{i} F_{i}\left(F_{i}+1\right)+1}\right]=0,
$$

and after its differentiation:

$$
\frac{F_{i}\left[-a_{i} F_{i}-a_{i}\left(F_{i}+1\right)\right]}{\left[a_{i} F_{i}\left(F_{i}+1\right)+1\right]^{2}}+\frac{1}{a_{i} F_{i}\left(F_{1}+1\right)+1}=0,
$$

where

$$
\mathrm{a}_{\mathrm{i}}=\frac{\mathrm{q}_{\mathrm{i}} \mathrm{M}_{\mathrm{R} . \mathrm{i}} \mathrm{S}_{\mathrm{E} . \mathrm{i}}}{\mathrm{Q}_{\mathrm{E} . \mathrm{i}}}
$$

The solution of Equation (12) is:

$$
-\mathrm{a}_{\mathrm{i}} \mathrm{F}_{\mathrm{i}}^{2}+1=0
$$

We can define the second condition for the function as:

$$
\mathrm{C}_{\mathrm{i}}^{\prime \prime}\left(\mathrm{F}_{\mathrm{i}(0)}\right)=-2 \mathrm{a}_{\mathrm{i}}<0 .
$$

Thus, the point $F_{i(0)}$ is the point of the local maximum of the function $C_{i}$. 
After its transformation, Equation (16), the finite (limited) production capacity of the $i$-th MFM building of the city cluster, can be given as:

$$
\mathrm{C}_{\mathrm{F} . \mathrm{i}}=\frac{\mathrm{Q}_{\mathrm{E} . \mathrm{i}} \mathrm{S}_{\mathrm{C} . \mathrm{i}}}{\mathrm{M}_{\mathrm{R} . \mathrm{i}} \mathrm{S}_{\mathrm{E} . \mathrm{i}} \mathrm{F}_{\mathrm{i}}^{2}}=\frac{\mathrm{C}_{\mathrm{E} . \mathrm{i}} \mathrm{S}_{\mathrm{C} . \mathrm{i}}}{\mathrm{S}_{\mathrm{E} . \mathrm{i}} \mathrm{F}_{\mathrm{i}}^{2}}
$$

where

$$
C_{E . i}=\frac{Q_{E . i}}{M_{R . i}} .
$$

The finite production capacity of the city MFM cluster is:

$$
\mathrm{C}_{\mathrm{F}}=\sum_{\mathrm{i}=1}^{\mathrm{k}} \frac{\mathrm{C}_{\mathrm{E} . \mathrm{i}} \mathrm{S}_{\mathrm{C} . \mathrm{i}}}{\mathrm{S}_{\mathrm{E} . \mathrm{i}} \mathrm{F}_{\mathrm{i}}^{2}}
$$

According to Equation (16), the finite MPW generation capacity in the city MFM cluster can be given as [22]:

$$
W_{F}=\sum_{r=1}^{10} \sum_{j=1}^{n} N_{R 0 . j} \sum_{i=1}^{k} \frac{C_{E . i} S_{C . i}}{S_{E . i} F_{i}^{2}}
$$

The finite production capacity in the city MFM cluster reflects the actual production capacity reserve under supply uncertainty and allows us to find the need of the city MFM cluster in the freight transport fleet in the case of using the first two SSC scenarios.

The installed finite production capacity allows us to find the need of the city MFM cluster in the freight transport fleet in the case of using SSC scenarios 1 and 2 (Figure 5) [24]:

$$
\begin{gathered}
N_{T .1(2)}=C_{F} \sum_{i=1}^{k} \frac{T_{T . i}}{\lambda_{T . i}} ; \\
\lambda_{1(2)}=2 N_{T .1(2)} \sum_{i=1}^{k} \frac{2 \lambda_{T . i}}{K_{\lambda . i}},
\end{gathered}
$$

where

$$
\mathrm{T}_{\mathrm{T} . \mathrm{i} .1(2)}=\frac{2}{\mathrm{~K}_{\mathrm{TF} . \mathrm{i}} \mathrm{K}_{\mathrm{T} . \mathrm{i}}}\left(\frac{\mathrm{L}_{\mathrm{i}}}{\mathrm{v}_{\mathrm{T}}}+\frac{2 \lambda_{\mathrm{T} . \mathrm{t}} \mathrm{t}_{\mathrm{T} . \mathrm{i}}}{3600}\right) .
$$

The installed finite MPW generation capacity allows us to find the need of the city MFM cluster in the freight transport fleet of the municipal WTS for SSC Scenarios 3-6 (Figure 5):

$$
\begin{aligned}
N_{T .3-6} & =\frac{W_{F}}{\lambda_{T}} \sum_{i=1}^{k} T_{T . i .3-6} ; \\
\lambda_{3-6} & =\frac{4 k \lambda_{T} N_{T .3-6}}{K_{\lambda}}
\end{aligned}
$$

where

$$
T_{T . i .3-6}=\frac{2}{K_{T F . i} K_{T . i}}\left(\frac{k_{T . i .5-6} L_{T . i .3-6}}{v_{T}}+\frac{2 \lambda_{T . i} t_{T . i}}{3600}\right) .
$$

The finite MPW generation capacity in the city MFM cluster and the corresponding transport fleet constitute the initial information for choosing sustainable scenarios of SSC and SSCM technologies for the MPW shipment in the framework of the circular economy concept and under supply uncertainty. The decrease in the finite MPW generation capacity in the city MFM cluster is associated with its sustainable development, in which the share of the use of green nonwaste production technologies and products is increased. 


\subsection{SSCM Technologies for the MPW Shipment from the City MFM Cluster's Enterprises}

The sustainable development of smart cities and CM4.0 is linked to the implementation of SSCM. The main goal of SSCM in the framework of sustainable development of a city MFM cluster and under supply uncertainty is to reduce the lead time and the costs of transport services, overstocking of cluster's enterprises and the CLN, and the freight traffic by increasing the share of full handling of MFM buildings. The MPW delivery from the city MFM cluster to the WTSs of the RTEP is integrated into the overall SSC, and one of the ISWM tasks is therefore to consider the features of using SSCM technologies for MPW shipment.

The use of a variety of deployed systems and instrumentation (e.g., sensors, radiofrequency identification (RFID) tags, meters, actuators, recording devices, tokens, Wi$\mathrm{Fi}$, and GPS) makes it possible to recognize any situations related to SC planning and implementation in real time (Figure 8), allowing for the prompt resolution of emerging uncertainties. The IRT positioning technology increases SSCM effectiveness and efficiency by reducing human workforce, worktime, and overall cost. The IRT operator or virtual operator with machine intelligence can take advantage of repeatable aggregated and analyzed data, automated and precise motion, etc. This approach could be considered as a key requirement in SSC [31].

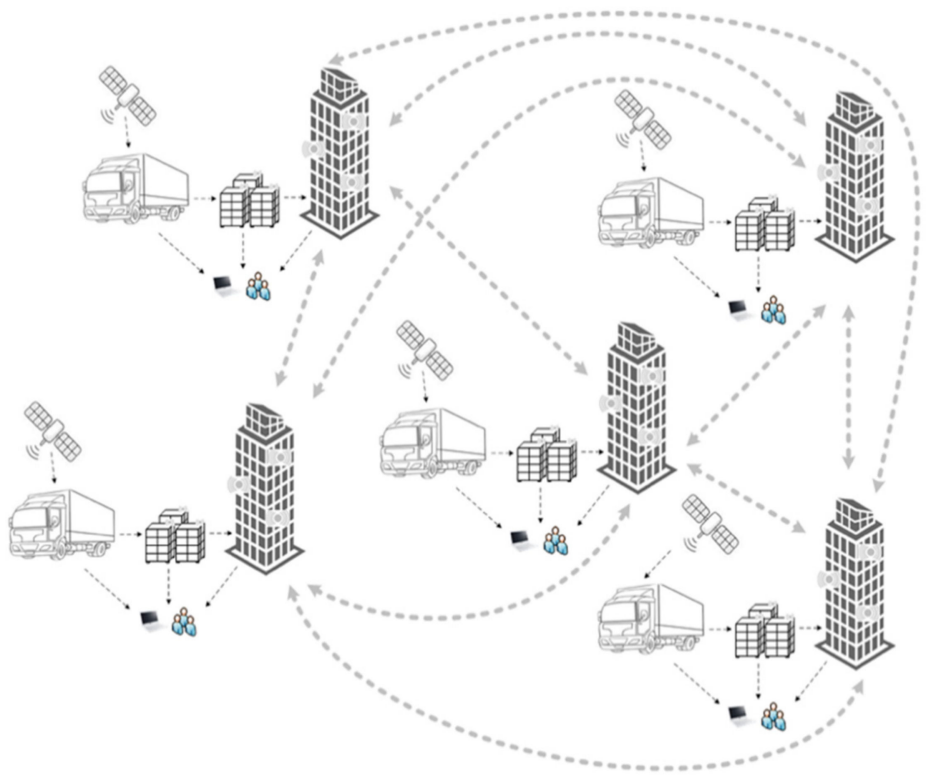

Figure 8. Monitoring in the SSC of the city MFM cluster [31].

The SSCM features for the MPW shipment from the city MFM cluster are as follows:

- use of blockchain technologies to create information support for the SSCM and a more complete use of the MPW in the framework of the circulation economy;

- distribution of input IRTs on the production floor for products or goods and for MPW, determination of the need for additional IRTs, including buffer IRTs for the MPW, and ensuring their delivery in the required time;

- monitoring the filling of IRT with MPW using video cameras and a weight sensor and recording device installed on the IRT;

- MPW certification with registration in the blockchain and in the recording device in the IRT for the MPW collection and shipment;

- reading the data of the MPW certificate from the IRT recording device to determine the possibility of joint transportation with other freights in the multi-IRT and combining the MPW collections by type when they are reloaded at the CLN or at municipal WTSs;

- reading and transfering data from the IRT weight sensor by the recording device to predict the time of its shipment; 
- establishment of the order of loading the IRTs into the truck to form multi-IRTs, according to which they are unloaded and loaded into the MFM building's freight elevators or are serviced at the CLN;

- reading the delivery address by the freight elevator from the IRT recording device for its automatic transportation to the corresponding floor of the MFM building;

- searching for a rational scenario for the MPW shipment and a combination of delivery/shipment of the IRTs in order to allow for the full or quasi-full handling of the MFM buildings;

- choosing a rational scenario for the delivery and shipment of goods and MPW by means of IRTs and the timely formation of routes for trucks in real time, considering the changing situation in the SC;

- decision-making by the machine intelligence of the SSCM system without any external forces in order to reduce the influence of the IRT operator's subjectivity;

- real-time monitoring of the IRT's location and the weight of its freight at all stages of its movement and transformation, with the addition of the necessary information in the freight's blockchain certificate;

- timely informing the operators of the IRTs and trucks about the need to perform certain unloading and loading operations in cases of the joint transportation of freights in the multi-IRT;

- duplicating all entries in the blockchain of the IRT's recording device;

- real-time monitoring of SSCM performance indicators in the city MFM cluster, considering the handling data of the MFM buildings for each vehicle.

The SSCM for the MPW shipment should be evaluated in terms of the system's effectiveness, practicality, usability, proactivity, and financial feasibility by industry experts. This approach can even further enhance any given standard system of SC management with functionality that perfectly matches the needs of the IRT operator/virtual operator. The benefits may include better routing, monitoring, and error preventing methods. Further analysis may indicate possible side effects due to the implementation of a scenario of the MPW shipment [31].

The SSCM performance indicators in the framework of a city MFM cluster is defined as the utilization rate of cases of the full handling and of the total cases of the full, quasi-full, and partial handling of the MFM buildings during a predetermined time period:

$$
\begin{aligned}
& \mathrm{E}_{\mathrm{HF} . \mathrm{d}(\mathrm{w})}=\frac{\sum_{\mathrm{i}=1}^{\mathrm{k}} \mathrm{J}_{\text {HF.d(w) }}}{\sum_{\mathrm{i}=1}^{\mathrm{k}} \mathrm{J}_{\mathrm{HF} . \mathrm{d}(\mathrm{w})}+\mathrm{J}_{\text {HQ.d }(\mathrm{w})}+\mathrm{J}_{\mathrm{HP} . \mathrm{d}(\mathrm{w})}} ; \\
& \mathrm{E}_{\mathrm{H} . \mathrm{d}(\mathrm{w})}=\frac{\sum_{\mathrm{i}=1}^{\mathrm{k}} \mathrm{J}_{\mathrm{HF} . \mathrm{d}(\mathrm{w})}+0.75 \mathrm{~J}_{\mathrm{HQ} . \mathrm{d}(\mathrm{w})}+0.5 \mathrm{~J}_{\mathrm{HP} . \mathrm{d}(\mathrm{w})}}{\sum_{\mathrm{i}=1}^{\mathrm{k}} \mathrm{J}_{\mathrm{HF} . \mathrm{d}(\mathrm{w})}+\mathrm{J}_{\mathrm{HQ} . \mathrm{d}(\mathrm{w})}+\mathrm{J}_{\mathrm{HP} . \mathrm{d}(\mathrm{w})}} .
\end{aligned}
$$

The proposed indicators of the SSCM performance also characterize the renewability of resources and the degree of the city MFM cluster's involvement in the implementation of the concept of a circular economy. It is obvious that the output of the IRTs with the MPW from the cluster, their entrance into the WTSs of the RTEP, the processing of the MPW into materials, and the loading of them into IRTs, with their subsequent return to the cluster, constitute a cyclical movement of materials aimed at their multiple use.

\subsection{Case Study}

The analysis of the obtained dependencies (19) and (21) shows that the finite production capacity and finite MPW generation capacity are significantly affected by the number of production floors of the MFM building. With the same floor areas for production and freight elevators, the finite production capacity of each floor of the MFM building decreases as the number of floors of the building increases due to the limited capacity of freight elevators. Additionally, the finite production capacity of the MFM building decreases with the growth of the number of its production floors. 
Figure 9 shows different solutions for the relative production area $\mathrm{S}_{\mathrm{C} . \mathrm{i}} / \mathrm{S}_{\mathrm{E} . \mathrm{i}}$ versus the relative production capacity $\mathrm{C}_{\mathrm{P} . \mathrm{i}} / \mathrm{C}_{\mathrm{E} . \mathrm{i}}$ of the MFM building, depending on the number $\mathrm{F}_{\mathrm{i}}$ of its production floors. The greatest influence on the relative production capacity of a building is the number of its floors. As the number of production floors increases, the relative production capacity is significantly reduced. Therefore, in the MFM buildings, the upper floors are used for nonproduction purposes [77].

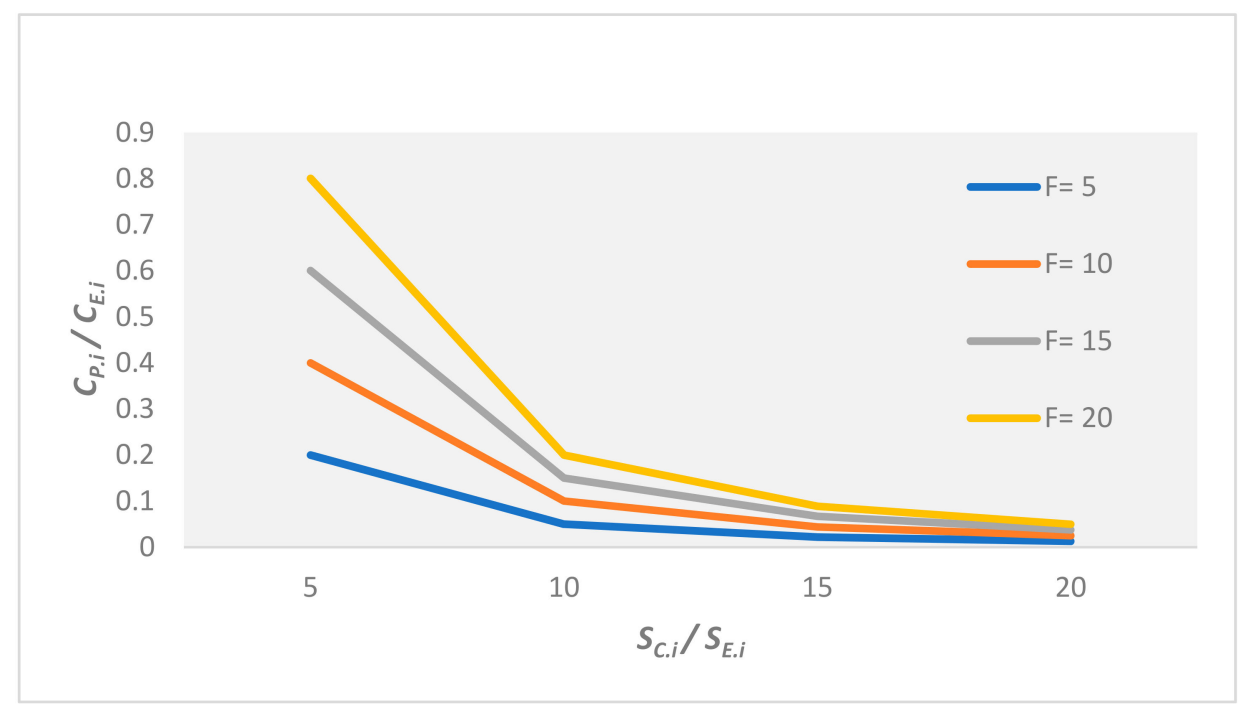

Figure 9. Different solutions for $\mathrm{S}_{\mathrm{C} . \mathrm{i}} / \mathrm{S}_{\mathrm{E} . \mathrm{i}}$ versus $\mathrm{C}_{\mathrm{P} . \mathrm{i}} / \mathrm{C}_{\mathrm{E} . \mathrm{i}}$ depending on the number of production floors $\mathrm{F}$ in the $\mathrm{MFM}$ building.

It should be highlighted that with an increase in the number of floors of the MFM building, the probability of the multi-IRT picking with only MPW for their shipment to the municipal WTS station increases, according to scenarios 3 and 4. The use of scenarios 3 and 4 contributes to the unloading of the CLN, reducing both the number of trucks used in the SC of MPW and the loading-unloading operations.

The analysis of Equations (22) and (25) shows that the average values of the parameter $\mathrm{T}_{\mathrm{T} . \mathrm{i} .1(2)}$ directly affect the number of units of the truck fleet of the cluster. Considering that scenarios 1 and 2 of the MPW shipment are the main ones, an important factor in the efficient use of the truck fleet is the reduction in the round trip time $\mathrm{T}_{\text {T.i.1(2) }}$, which is facilitated by the location of the CLN node in the central part of the city MFM cluster $[5,17,21]$.

The proposed indicators of SSCM performance are characterized by the efficiency of the use of vehicles within the city MFM cluster in the transportation of various freights, including MPW and recycled materials. A more complete use of vehicles helps to reduce urban traffic and the environmental impact of transport activities. The SSCM performance indicator $\mathrm{E}_{\mathrm{HF} . \mathrm{d}(\mathrm{w})}$ also characterizes the closed-loop recycling of materials, conversion of them into a new product, and their return to the consumer. The higher the value of the SSCM performance indicators, the more efficiently vehicles are used and so a closed-loop recycling of materials is implemented, which has a positive impact on the sustainable development of the cluster and the huge city as a whole.

Table 1 shows the day-of-the-week effects on SSCM performance indicators of various options regarding the handling of the city MFM building by trucks. Option 1 (Op 1) involves 100\% partial handling of the manufacturing building; Option $2(\mathrm{Op} 2)$ involves $60 \%$ partial, $20 \%$ quasi-full, and 20\% full handling of the manufacturing building; Option 3 (Op 3) involves $40 \%$ partial, $40 \%$ quasi-full, and $20 \%$ full handling of the manufacturing building; Option 4 (Op 4) involves 100\% quasi-full handling of the manufacturing building; Option 5 (Op 5) involves 20\% partial, $40 \%$ quasi-full, and $40 \%$ full handling of the manufacturing building; Option $6(\mathrm{Op} 6$ ) involves $20 \%$ partial, $20 \%$ quasi-full, and $60 \%$ full 
handling of the manufacturing building; Option 7 (Op 7) involves 100\% full handling of the manufacturing building.

Table 1. Day-of-the-week effects on SSCM performance indicators of various options regarding the handling of the city MFM building by trucks.

\begin{tabular}{|c|c|c|c|c|c|c|c|}
\hline \multirow{2}{*}{$\begin{array}{l}\text { Number of MFM } \\
\text { Buildings in Cluster }\end{array}$} & \multicolumn{5}{|c|}{$\begin{array}{l}\text { Options Regarding the Handling of the City MFM Buildings and Indicators } \\
\qquad E_{H F . d} \text { and } E_{H . d} \text { for Days of the Week }\end{array}$} & \multirow[t]{2}{*}{$\mathrm{E}_{\mathrm{HF} . w}$} & \multirow[t]{2}{*}{$\mathrm{E}_{\mathrm{H} . \mathrm{w}}$} \\
\hline & Monday & Tuesday & Wednesday & Thursday & Friday & & \\
\hline 1 & Op2; 0.2; 0.65 & Op4; $0 ; 0.75$ & Op3; 0.2; 0.75 & Op5; $0.4 ; 0.8$ & Op5; $0.4 ; 0.8$ & 0.24 & 0.75 \\
\hline 2 & Op7; $1.0 ; 1.0$ & Op1; 0; 0.5 & Op6; 0.6; 0.85 & Op5; $1.0 ; 1.0$ & Op4; $0 ; 0.75$ & 0.52 & 0.82 \\
\hline 3 & Op3; $0.2 ; 0.75$ & Op7; $1.0 ; 1.0$ & Op $2 ; 0.2 ; 0.65$ & Op6; $0.6 ; 0.85$ & Op4; $0 ; 0.75$ & 0.40 & 0.80 \\
\hline 4 & Op5; $0.4 ; 0.8$ & Op1; 0; 0.5 & Op7; 1.0; 1.0 & Op4; $0 ; 0.75$ & Op5; 0.4; 0.8 & 0.36 & 0.77 \\
\hline 5 & Op6; $0.6 ; 0.85$ & Op5; $0.4 ; 0.8$ & Op3; $0.2 ; 0.75$ & Op7; $1.0 ; 1.0$ & Op2; $0.2 ; 0.65$ & 0.48 & 0.81 \\
\hline
\end{tabular}

In accordance with the data in Table 1, the average values of the indicators $\widetilde{\mathrm{E}}_{\mathrm{HF} . \mathrm{w}}$ and $\widetilde{\mathrm{E}}_{\mathrm{H} . \mathrm{w}}$ for the considered days of the week were 0.4 and 0.79 , respectively. The results obtained in this study show that, for the days of the week under consideration, the share of the full handling of the city MFM buildings of the cluster was 0.4 in the total handling of the city MFM buildings, and the share of the loss of the capacity (throughput) of the truck fleet due to their empty runs was $1-0.79=0.21$ or $21 \%$. Increasing the share of full and quasi-full handling in the total handling of the city MFM buildings improves the efficiency of the SSC for MPW due to the more complete use of the throughput of the freight transport serving the cluster.

The discussion and conclusions of the results obtained herein are presented below, along with additional findings, limitations, and further future research recommendations.

\section{Discussion}

The ISWM using SSC technology depends on the timeliness, completeness, and reliability of information on a wide range of MPW-related issues: the type and intensity of the generation, location, ownership, supply time and terms, SC scenario, sustainability, and safety of the supply, monitoring, and control of delivery, etc. The type and intensity of MPW generation depends on the type and plan of production, the materials used, as well as on the selected technological equipment. Therefore, it is important to have enough information to select the appropriate technological equipment and products in order to meet customer needs with minimal MPW generation. It is obvious that ISWM information support is a fundamental factor for the sustainable development of the city MFM cluster. For this purpose, blockchain technology is used, which has found an application not only in the financial sphere, but also in the field of SC [78-81], manufacturing [13,14,67], and waste $[78,79,82]$ management.

Every product (piece of technological equipment), IRT, and its freight is provided with an identifier that links them to the information support in the blockchain and, as a result, allows for the implementation of the concept of IoT $[15,82,83]$. The access to (recording of) information in the blockchain can be open or limited (only for a certain circle of physical and virtual consumers (sources) of information). The information is recorded in the corresponding blockchain in real time, both manually and automatically, by physical or virtual actors who have received permission to enter new information. The information in the blockchain is saved and updated automatically each time a change is initiated [84,85].

Thus, blockchain technology provides timely, complete, and reliable information in the framework of the IoT concept [62,83] and can be applied in the city MFM cluster to implement the ISWM using SSC in the following ways:

1. The information support of blockchain technology is implemented for the certification of technological equipment at the stage of its manufacture, technology sustainability 
assessment, integration of sustainability with the production and design of manufactured products, life cycle assessment of products, waste management, etc. [66,78,86-90]. This information, along with tracing sustainability values in the history of materials (including MPW, methods of their processing, assessment of the possibility of using the obtained materials in various operating conditions, etc.), and similar products [78] can be used to decide on the possibility of using selected technologies and manufactured products in the city MFM cluster. It is obvious that when choosing sustainable technologies and manufactured products for the city MFM cluster, nonwaste technologies and technologies that do not require additional measures (cleaning, filtering, etc.) to protect the environment and human health are preferred;

2. The organization of production in the city MFM cluster is associated with the grouping of production buildings by related technologies and primarily by the materials used and generated MPW. This grouping of production buildings reduces the range of transported freights and simplifies the tracing of material flows, allowing for decisionmaking concerning the compatibility of goods in IRTs for their transportation as city containers $[13,21,28,77]$. The information basis for the decision-making process in the cases considered could also be data obtained using the blockchain technology [28];

3. The information provided by blockchain technology about the products already available on the market can be used to study consumer demand for innovative products at the stage of their development in ATEPs, quality and safety issues, their further application in the framework of multi-R strategies [23] for the implementation of the circular economy concept. It is obvious that the proposed scenarios for the MPW shipment and the model of ISWM using SSC technology could also be used for ATEPs that produce both pilot batches of innovative products and products for urban needs during the educational and training processes, resulting in production waste. These products are produced in small volumes, and the intensity of MPW generation in ATEPs is therefore significantly lower compared to the city MFM cluster, which simplifies the shipment of such waste;

4. The blockchain technology can be used to identify the location of IRTs and their freights (e.g., MPW location) in real time. The "Location Component" standard of the Blockchain in Transport Alliance for the determination of the location of a mobile entity is already being used. Further developments of blockchain technology are expected to expand its capabilities in the transport and logistics sector in order to determine and establish norms and rules for the management of transport, logistics flows, and activities, as well as the control of vehicles and conditions of freight transportation [80];

5. Blockchain technology can also be used to inform stakeholders about the safety of vehicles and transported goods for human health [78]. The implementation of a safe SSC in the context of the pandemic or active virus threat to human health is a priority that is currently receiving much attention [91,92]. One of the tasks with the highest priority at present is the automatic decontamination of IRTs and multi-IRTs with their freights only during their transportation in freight elevators and trucks using special devices-for example, portable flash xenon ultraviolet lamps [93]. The implementation of rapid disinfection technology in IRTs, especially ultraviolet (UV) xenon lamps, in a short period of their transportation within the city MFM cluster is associated with the following requirements:

- UV pulsed xenon lamps should be installed in the bodies of all freight elevators and trucks;

- the bactericidal efficiency of installed UV pulse xenon lamps should guarantee the effective decontamination of external surfaces of transported IRTs and multi-IRTs with their freights from mold fungi, mycobacteria, and viruses;

- the decontamination procedure should be performed only during the transportation of IRTs and multi-IRTs, regardless of the freight presence in them (the maximum duration of UV exposure should not exceed the recommended time for this procedure);

- information about the received UV radiation doses at each stage of transportation of the IRTs and their freights should be automatically read from the sensors of the 
freight elevator and truck by the IRT recording device and transmitted to the server of the CLN for the rapid assessment of the degree of their disinfection and subsequent storage in the account of the corresponding vehicles and transported freights using blockchain technology;

- operators of vehicles and of the CLN, owners of IRTs, and suppliers and consumers of freights should be subjected to real-time assessments of the degree of their decontamination and the danger to personnel.

The information about the decontamination of IRTs and their freights at all stages of transportation can also be recorded using the blockchain technology;

6. The stability and immutability of the information provided by blockchain technology is a guarantee of reliable information about compliance with environmental and safety standards by the city MFM cluster's enterprises, as well as the observance of human rights and fair and safe working practices. The accessibility to open and transparent blockchain information about the nature and safety of MPW and the SSC in the framework of the cluster for both stakeholders, certifying and standardizing organizations, and the citizens as a whole contributes to the socialization of the monitoring and control over the sustainable development of the manufacturing structures of a huge city $[78,84,94]$.

\section{Conclusions}

This study presents the ISWM for a city MFM cluster under supply uncertainty. The main innovative, informational, distribution, and transport points and links of the city MFM clusters within a huge city and agglomeration, as well as their role in the generation, sorting, and processing of MPW, are considered. MPW shipment scenarios from the manufacturing enterprises of the city cluster are presented, considering the established finite capacity of their generation and the required number of vehicles for their transportation.

The main MPW shipment scenario provides for the transportation of containers in the city, together with other freights, to the CLN, where it is disassembled, sorted by IRTs, and shipped by city containers to customers and the WTS [21]. Given the combined transportation of freights and MPW in the city containers through the CLN, there is a need to determine not only the finite MPW generation capacity, but also the finite production capacity of the MFM buildings of the cluster. The presented model can be used to calculate the production capacity of the MFM building, taking into account the accepted restrictions. It allows one to make calculations that show exactly how the production capacity decreases as the number of floors increases. The influence of the number of floors in the building, the ratio of the production area, and the area occupied by freight elevators on the finite production capacity and the finite MPW generation capacity is established. As the number of floors in production buildings increases, the finite production capacity of each floor decreases. Therefore, on the last floors of high-rise buildings, it is advisable to place nonproduction enterprises [77].

In the context of supply uncertainty, the main MPW shipment scenario can lead to the CLN becoming overloaded and disruptions in the SC. For these conditions, alternative MPW shipment scenarios are proposed. The selection of the best scenario for the MPW shipment from the city MFM cluster in real time is carried out using SSC technologies. The key aspects of the SSCM for the MPW shipment from enterprises of the city cluster MFM and their performance indicators are presented. The selection of the best scenario for the MPW shipment from the city MFM cluster in real time is carried out using SSC technologies. The key aspects of the SSCM for the MPW shipment from enterprises of the city cluster MFM and their performance indicators are presented. The SSCM performance indicators in the framework of the city MFM cluster are based on the utilization rates of the full handling and of the total cases of the full and quasi-full handling of the MFM buildings during a predetermined time period. The proposed SSCM performance indicators characterize the workload of vehicles during the MPW transportation or the share of empty runs of vehicles (IRTs and trucks) in the total volume of traffic, as well as the degree of involvement of the city MFM cluster in the implementation of the concept of a circular economy. 
In this paper, issues are discussed that relate to the use of blockchain technology for information support for the identification of IRTs and their freights in real time and the assessment of the sustainability of the technologies used, product life cycle, and waste management, consumer demand for innovative products at the stage of their development, quality, and safety, their further application, the safety of vehicles and transported freights for human health. The advantages of grouping city MFM buildings by related technologies, the materials used, and the generated waste for reducing the range of transported goods, simplifying the control of material flows, and facilitating decision-making concerning the compatibility of transported freights in the multi-IRT are also discussed.

This paper presents the ISWM for a city MFM cluster using various SSC scenarios for MPW shipment under supply uncertainty. However, several key issues were not adequately examined, such as sustainable SC management within the city MFM cluster based on the established TBL assessment criteria [15,26], the compatibility of transported freights in multi-IRTs, as well as the effectiveness of decision-making in the implementation of SSCM, which are also of interest for further research.

Author Contributions: Conceptualization, T.D. and A.D.; methodology, T.D. and A.D.; software, T.D. and A.D.; validation, T.D. and A.D.; formal analysis, T.D.; resources, A.D.; data curation, T.D. and A.D.; writing — original draft preparation, T.D. and A.D.; writing—review and editing, T.D. and A.D.; visualization, T.D. and A.D.; supervision, A.D. and T.D. All authors have read and agreed to the published version of the manuscript.

Funding: This research was funded by the Maritime University of Szczecin; 1/s/WIET/PUB/21.

Institutional Review Board Statement: Not applicable.

Informed Consent Statement: Not applicable.

Data Availability Statement: Not applicable.

Conflicts of Interest: The authors declare no conflict of interest.

$\begin{array}{ll}\text { Abbreviations } \\ \text { ATEP } & \begin{array}{l}\text { advanced technology and education park } \\ \text { city logistics node }\end{array} \\ \text { CLN } & \text { city manufacturing } 4.0 \\ \text { CM4.0 } & \text { capacity requirements planning } \\ \text { CRP } & \text { cyber-physical Systems } \\ \text { CPS } & \text { external transfer and buffer zone } \\ \text { ETBZ } & \text { Global Positioning System } \\ \text { GPS } & \text { industry } 4.0 \\ \text { I4.0 } & \text { information and communications technology } \\ \text { ICT } & \text { intelligent reconfigurable trolley } \\ \text { IRT } & \text { integrated sustainable waste management } \\ \text { ISWM } & \text { internal transfer and buffer zone } \\ \text { ITBZ } & \text { long range } \\ \text { LoRa } & \text { internet of things } \\ \text { LoT } & \text { material flow analysis } \\ \text { MFA } & \text { multifloor manufacturing } \\ \text { MFM } & \text { municipal nonproduction waste } \\ \text { MNPW } & \text { municipal production waste } \\ \text { MPW } & \text { radio-frequency identification } \\ \text { RFID } & \text { recycling, treatment, and energy park } \\ \text { RTEP } & \text { supply chain } \\ \text { SC } & \text { supply chain management } \\ \text { SCM } & \text { smart supply chain } \\ \text { SSC } & \end{array}$


SSCM smart supply chain management

TBL triple bottom line

UV Ultraviolet

Wi-Fi wireless fidelity

WTS waste transfer station

\section{References}

1. Bai, C.; Sarkis, J. Improving green flexibility through advanced manufacturing technology investment: Modeling the decision process. Int. J. Prod. Econ. 2017, 188, 86-104. [CrossRef]

2. Niaki, M.K.; Nonino, F. Additive manufacturing management: A review and future research agenda. Int. J. Prod. Res. 2017, 55, 1419-1439. [CrossRef]

3. Rauch, E.; Ciano, M.P.; Matt, D.T. Distributed manufacturing network models of smart and agile mini-factories. Int. J. Agil. Syst. Manag. 2017, 10, 185. [CrossRef]

4. Sarkis, J.; Zhu, Q. Environmental sustainability and production: Taking the road less travelled. Int. J. Prod. Res. 2018, 56, 743-759. [CrossRef]

5. Dzhuguryan, T.; Jóźwiak, Z.; Deja, A.; Semenova, A. Infrastructure and Functions of a City Logistics Node for Multi-Floor Manu-facturing Cluster. In Proceedings of the 8th International Scientific Conference (CMDTUR 2018), Žilina, Slovakia, 4-5 October 2018; pp. 196-201.

6. Westkämper, E. Towards the Re-Industrialization of Europe: A Concept for Manufacturing for 2030; Springer: Berlin, Geramny, 2014.

7. Lom, M.; Pribyl, O.; Svitek, M. Industry 4.0 as a part of smart cities. In Proceeding of the Smart City Symposium (SCSP 2016), Prague, Czech Republic, 26-27 May 2016. [CrossRef]

8. Ivanov, D.; Dolgui, A.; Sokolov, B.; Werner, F.; Ivanova, M. A dynamic model and an algorithm for short-term supply chain scheduling in the smart factory industry 4.0. Int. J. Prod. Res. 2016, 54, 386-402. [CrossRef]

9. Ivanov, D.; Dolgui, A.; Sokolov, B. The impact of digital technology and Industry 4.0 on the ripple effect and supply chain risk analytics. Int. J. Prod. Res. 2019, 57, 829-846. [CrossRef]

10. Ivanov, D.; Tang, C.S.; Dolgui, A.; Battini, D.; Das, A. Researchers' perspectives on Industry 4.0: Multi-disciplinary analysis and opportunities for operations management. Int. J. Prod. Res. 2020, 1-24. [CrossRef]

11. Liao, Y.; Deschamps, F.; Loures, E.D.F.R.; Ramos, L.F.P. Past, present and future of Industry 4.0-A systematic literature review and research agenda proposal. Int. J. Prod. Res. 2017, 55, 3609-3629. [CrossRef]

12. Romero, D.; Wuest, T.; Stahre, J.; Gorecky, D. Social Factory Architecture: Social Networking Services and Production Scenarios through the Social Internet of Things, Services and People for the Social Operator 4.0. In Advances in Production Management Systems. The Path to Intelligent, Collaborative and Sustainable Manufacturing; Lödding, H., Riedel, R., Thoben, K.D., von Cieminski, G., Kiritsis, D., Eds.; Springer International Publishing: Cham, Switzerland, 2017; pp. 265-273.

13. Jiang, P. Social Manufacturing: Fundamentals and Applications; Springer Series in Advanced Manufacturing; Springer: Berlin/Heidelberg, Germany, 2018; Available online: https://www.springer.com/gp/book/9783319729855 (accessed on 25 January 2021).

14. Wang, F.-Y.; Shang, X.; Qin, R.; Xiong, G.; Nyberg, T.R. Social Manufacturing: A Paradigm Shift for Smart Prosumers in the Era of Societies 5.0. IEEE Trans. Comput. Soc. Syst. 2019, 6, 822-829. [CrossRef]

15. Manavalan, E.; Kandasamy, J. A review of Internet of Things (IoT) embedded sustainable supply chain for industry 4.0 requirements. Comput. Ind. Eng. 2019, 127, 925-953. [CrossRef]

16. Fujita, M.; Thisse, J.-F. Economics of Agglomeration: Cities, Industrial Localization, and Globalization; Cambridge University Press (CUP): Cambridge, UK, 2002.

17. Fechner, I. Location conditionings of logistics centers as central units of national logistics network. Logist. Transp. 2011, 1, 23-32.

18. Dzhuguryan, T. Design Features of Flexible Manufacturing Modules in Frame Construction. Zesz. Nauk. Politech. Rzesz. Mech. Oficyna Wydawnicza Politech. Rzesz. 2012, 84, 21-25. Available online: http://yadda.icm.edu.pl/yadda/element/bwmeta1 .element.baztech-article-PWA9-0057-0017 (accessed on 27 January 2021).

19. Gilka, N.; Grigiryan, G.; Dzhuguryan, T.; Lichevski, P.; Markarov, G.; Pupin, A. Flexible Manufacturing Module. Patent SU 1380915A1, 21 November 1988. Available online: https:/ / www.elibrary.ru/item.asp?id=40427977 (accessed on 27 January 2021).

20. Dzhuguryan, L. Interactive monitoring and assessment of knowledge based on an adaptive learning system. Autobusy Tech. Eksploat. Syst. Transp. 2018, 19, 1051-1054. [CrossRef]

21. Deja, A.; Dzhuguryan, T. Environmental Sustainable Waste Management for a City Multi-Floor Manufacturing Cluster. Syst. Saf. Hum. Tech. Facil. Environ. 2019, 1, 457-464. [CrossRef]

22. Murray, A.; Skene, K.; Haynes, K. The Circular Economy: An interdisciplinary exploration of the concept and application in a global context. J. Bus. Ethics 2017, 140, 369-380. [CrossRef]

23. Potting, J.; Hekkert, M.; Worrell, E.; Hanemaaijer, A. Circular Economy: Measuring Innovation in the Product Chain; Policy Report; PBL Netherlands Environmental Assessment Agency: Den Haag, The Netherlands, 2017.

24. Wiśnicki, B.; Dzhuguryan, T. Integrated sustainable freight transport system for city multi-floor manufacturing clusters. MAPE 2019, 2, 151-160. [CrossRef] 
25. Mastos, T.D.; Nizamis, A.; Vafeiadis, T.; Alexopoulos, N.; Ntinas, C.; Gkortzis, D.; Papadopoulos, A.; Ioannidis, D.; Tzovaras, D. Industry 4.0 sustainable supply chains: An application of an IoT enabled scrap metal management solution. J. Clean. Prod. 2020, 269, 122377. [CrossRef]

26. Jemai, J.; Chung, B.D.; Sarkar, B. Environmental effect for a complex green supply-chain management to control waste: A sustainable approach. J. Clean. Prod. 2020, 277, 122919. [CrossRef]

27. Saxena, N.; Sarkar, B.; Singh, S. Selection of remanufacturing/production cycles with an alternative market: A perspective on waste management. J. Clean. Prod. 2020, 245, 118935. [CrossRef]

28. Dzhuguryan, T.; Deja, A.; Wiśnicki, B.; Jóźwiak, Z. The Design of Sustainable City Multi-Floor Manufacturing Processes Under Uncertainty in Supply Chains. Sustainability 2020, 12, 9439. [CrossRef]

29. Bondonio, D.; Greenbaum, R.T. Do local tax incentives affect economic growth? What mean impacts miss in the analysis of enterprise zone policies. Reg. Sci. Urban Econ. 2007, 37, 121-136. [CrossRef]

30. Zhao, Y.; Wang, H.-T.; Lu, W.-J.; Damgaard, A.; Christensen, T.H. Life-cycle assessment of the municipal solid waste management system in Hangzhou, China (EASEWASTE). Waste Manag. Res. 2009, 27, 399-406. [CrossRef]

31. Dudek, T.; Dzhuguryan, T.; Lemke, J. Sustainable production network design for city multi-floor manufacturing cluster. Procedia Comput. Sci. 2019, 159, 2081-2090. [CrossRef]

32. Dzhuguryan, T.; Wiśnicki, B.; Jóźwiak, Z. Modular Loading Units for Facilitating Multi-Floor Manufacturing and City Logistics. Sci. J. Maritime Univ. Szczecin 2018, 55, 73-78.

33. Dzhuguryan, T.; Wiśnicki, B.; Dudek, T. Concept of Intelligent Reconfigurable Trolleys for City Multi-Floor Manufacturing and Logistics System. In Proceedings of the 8th Carpathian Logistics Congress (CLC2018), Prague, Czech Republic, 3-5 December 2018; pp. 254-259.

34. Issaoui, Y.; Khiat, A.; Bahnasse, A.; Ouajji, H. Smart Logistics: Blockchain Trends and Applications. J. Ubiquitous Syst. Pervasive Netw. 2020, 12, 9-15. [CrossRef]

35. Wang, Y.; Ma, H.-S.; Yang, J.-H.; Wang, K. Industry 4.0: A way from mass customization to mass personalization production. Adv. Manuf. 2017, 5, 311-320. [CrossRef]

36. Roopa, M.; Sujitran, M.; Saivikas, S. Efficient Waste Management System for Smart City using LoRa. Int. J. Psychosoc. Rehabil. 2020, 24, 3465-3476.

37. McKinnon, A.C.; Ge, Y. The potential for reducing empty running by trucks: A retrospective analysis. Int. J. Phys. Distrib. Logist. Manag. 2006, 36, 391-410. [CrossRef]

38. Seadon, J.K. Sustainable waste management systems. J. Clean. Prod. 2010, 18, 1639-1651. [CrossRef]

39. Costa, I.; Massard, G.; Agarwal, A. Waste management policies for industrial symbiosis development: Case studies in European countries. J. Clean. Prod. 2010, 18, 815-822. [CrossRef]

40. Pires, A.; Martinho, G.; Chang, N.-B. Solid waste management in European countries: A review of systems analysis techniques. J. Environ. Manag. 2011, 92, 1033-1050. [CrossRef]

41. Elsaid, S.; Aghezzaf, E.-H. A framework for sustainable waste management: Challenges and opportunities. Manag. Res. Rev. 2015, 38, 1086-1097. [CrossRef]

42. Generowicz, A. Multi-Criteria Analysis of Waste Management in Szczecin. Pol. J. Environ. Stud. $2014,23$.

43. Gharfalkar, M.; Court, R.; Campbell, C.; Ali, Z.; Hillier, G. Analysis of waste hierarchy in the European waste directive 2008/98/EC. Waste Manag. 2015, 39, 305-313. [CrossRef] [PubMed]

44. Brzeszczak, A. Selective municipal waste collection system in Poland-Analysis of the amount and structure of collected waste in Poland. World Sci. News 2020, 144, 183-195.

45. Łapko, A.; Strulak-Wójcikiewicz, R.; Landowski, M.; Wieczorek, R. Management of Waste Collection from Yachts and Tall Ships from the Perspective of Sustainable Water Tourism. Sustainability 2018, 11, 121. [CrossRef]

46. Deja, A.; Strulak-Wójcikiewicz, R.; Kaup, M. Management of Ship-Generated Waste Reception at the Port of Szczecin as a Key Component in the Reverse Logistics Chain. In Sustainable Design and Manufacturing, Proceedings of the International Conference on Sustainable Design and Manufacturing (KES-SDM 2019), Budapest, Hungary, 4-5 July 2019; Smart Innovation, Systems and Technologies; Ball, P., Huatuco, L., Howlett, R., Setchi, R., Eds.; Springer: Singapore, 2019; Volume 155, pp. 533-543, ISBN 978-981-13-9270-2. [CrossRef]

47. Kirchherr, J.; Reike, D.; Hekkert, M. Conceptualizing the circular economy: An analysis of 114 definitions. Resour. Conserv. Recycl. 2017, 127, 221-232. [CrossRef]

48. Cobo, S.; Dominguez-Ramos, A.; Irabien, A. From linear to circular integrated waste management systems: A review of methodo-logical approaches. Resour. Conserv. Recycl. 2018, 135, 279-295. [CrossRef]

49. Sánchez-Flores, R.B.; Cruz-Sotelo, S.E.; Ojeda-Benitez, S.; Ramírez-Barreto, M.E. Sustainable Supply Chain Management-A Literature Review on Emerging Economies. Sustainability 2020, 12, 6972. [CrossRef]

50. Saeed, M.A.; Kersten, W. Drivers of Sustainable Supply Chain Management: Identification and Classification. Sustainability 2019, 11, 1137. [CrossRef]

51. Ahi, P.; Searcy, C. Assessing sustainability in the supply chain: A triple bottom line approach. Appl. Math. Model. 2015, 39, 2882-2896. [CrossRef]

52. Sauer, P.C.; Seuring, S. A three-dimensional framework for multi-tier sustainable supply chain management. Supply Chain Manag. Int. J. 2018, 23, 560-572. [CrossRef] 
53. Hong, J.; Zhang, Y.; Ding, M. Sustainable supply chain management practices, supply chain dynamic capabilities, and enterprise performance. J. Clean. Prod. 2018, 172, 3508-3519. [CrossRef]

54. Saxena, N.; Singh, S.R.; Sana, S.S. A green supply chain model of vendor and buyer for remanufacturing. Oper. Res. 2017, 51, 1133-1150. [CrossRef]

55. Fatorachian, H.; Kazemi, H. Impact of Industry 4.0 on supply chain performance. Prod. Plan. Control. 2021, 32, 63-81. [CrossRef]

56. Wu, L.; Yue, X.; Jin, A.; Yen, D.C. Smart supply chain management: A review and implications for future research. Int. J. Logist. Manag. 2016, 27, 395-417. [CrossRef]

57. Abdel-Basset, M.; Manogaran, G.; Mohamed, M. Internet of Things (IoT) and its impact on supply chain: A framework for building smart, secure and efficient systems. Futur. Gener. Comput. Syst. 2018, 86, 614-628. [CrossRef]

58. Abdel-Basset, M.; Gunasekaran, M.; Mohamed, M.; Chilamkurti, N. A framework for risk assessment, management and evaluation: Economic tool for quantifying risks in supply chain. Future Gener. Comput. Syst. 2019, 93, 1076-1077. [CrossRef]

59. Zhao, J.; Ji, M.; Feng, B. Smarter supply chain: A literature review and practices. J. Data Inf. Manag. 2020, 2, 95-110. [CrossRef]

60. Shaoa, X.-F.; Liu, W.; Lia, Y.; Chaudhry, H.R.; Yuec, X.-G. Multistage implementation framework for smart supply chain management under industry 4.0. Technol. Forecast. Soc. Chang. 2021, 162, 120354. [CrossRef]

61. Windmark, C.; Kianian, B.; Andersson, C. Assessment of a cost-model on sustainability for a proposal for a framework for the evaluation of sustainable manufacturing. Int. J. Manuf. Res. 2020, 15, 22. [CrossRef]

62. Esmaeilian, B.; Sarkis, J.; Lewis, K.; Behdad, S. Blockchain for the future of sustainable supply chain management in Industry 4.0. Resour. Conserv. Recycl. 2020, 163, 105064. [CrossRef]

63. Ralston, P.; Blackhurst, J. Industry 4.0 and resilience in the supply chain: A driver of capability enhancement or capability loss? Int. J. Prod. Res. 2020, 58, 5006-5019. [CrossRef]

64. Ullah, M.; Sarkar, B. Smart and sustainable supply chain management: A proposal to use RFID to improve electronic waste management. In Proceedings of the International Conference on Computers and Industrial Engineering, Auckland, New Zealand, 2-5 December 2018; pp. 1-15.

65. Anschutz, J.; IJgosse, J.; Scheinberg, A. Putting Integrated Sustainable Waste Management into Practice Using the ISWM Assessment Methodology: ISWM Methodology as Applied in the UWEP Plus Programme (2001-2003); WASTE: Gouda, The Netherlands, 2004.

66. Kluczek, A. Application of Multi-criteria Approach for Sustainability Assessment of Manufacturing Processes. Manag. Prod. Eng. Rev. 2016, 7, 62-78. [CrossRef]

67. Dzhuguryan, T.; Jóźwiak, Z. Specific Approach to Assessment of Technologies for Multi-Floor Manufacturing System. AutobusyTech. Eksploat. Systemy Transp. 2017, 6, 1656-1659.

68. Bai, C.; Ciano, M.P.; Orzes, G.; Sarkis, J. Industry 4.0 technologies assessment: A sustainability perspective. Int. J. Prod. Econ. 2020, 229, 107776. [CrossRef]

69. Rigamonti, L.; Sterpi, I.; Grosso, M. Integrated municipal waste management systems: An indicator to assess their environmental and economic sustainability. Ecol. Indic. 2016, 60, 1-7. [CrossRef]

70. Jodlbauer, H.; Reitner, S. Material and capacity requirements planning with dynamic lead times. Int. J. Prod. Res. 2012, 50, 4477-4492. [CrossRef]

71. Allesch, A.; Brunner, P.H. Material Flow Analysis as a Decision Support Tool for Waste Management: A Literature Review. J. Ind. Ecol. 2015, 19, 753-764. [CrossRef]

72. Moriguchi, Y.; Hashimoto, S. Material Flow Analysis and Waste Management. In Taking Stock of Industrial Ecology; Clift, R., Druckman, A., Eds.; Springer: Cham, Switzerland, 2016. [CrossRef]

73. Nakamura, S.; Kondo, Y. Toward an integrated model of the circular economy: Dynamic waste input-output. Resour. Conserv. Recycl. 2018, 139, 326-332. [CrossRef]

74. Dzhuguryan, T.; Jóźwiak, Z. Improving the logistics of the multi-floor assembly manufacturing. Technol. Autom. Montaż. 2016, 2, 16-20.

75. Lithner, D.; Larsson, Å.; Dave, G. Environmental and health hazard ranking and assessment of plastic polymers based on chemical composition. Sci. Total. Environ. 2011, 409, 3309-3324. [CrossRef] [PubMed]

76. Wahlström, M.; Laine-Ylijoki, J.; Wik, O.; Oberender, A.; Hjelmar, O. Hazardous Waste Classification: Amendments to the European Waste Classification Regulation-What Do They Mean and What Are the Consequences? Nordic Council of Ministers: Copenhagen, Denmark, 2016.

77. Dzhuguryan, T.; Jóźwiak, Z. Infrastructure for Multi-Floor Virtual Enterprises System. Syst. Support. Prod. Eng. 2016, 3, 70-78.

78. Kouhizadeh, M.; Sarkis, J. Blockchain Practices, Potentials, and Perspectives in Greening Supply Chains. Sustainability 2018, 10, 3652. [CrossRef]

79. Saberi, S.; Kouhizadeh, M.; Sarkis, J. Blockchain technology: A panacea or pariah for resources conservation and recycling? Resour. Conserv. Recycl. 2018, 130, 80-81. [CrossRef]

80. Koh, S.L.; Dolgui, A.; Sarkis, J. Blockchain in transport and logistics-paradigms and transitions. Int. J. Prod. Res. 2020, 58, 2054-2062. [CrossRef]

81. Bai, C.; Sarkis, J. A supply chain transparency and sustainability technology appraisal model for blockchain technology. Int. J. Prod. Res. 2020, 58, 2142-2162. [CrossRef] 
82. Ongena, G.; Smit, K.; Boksebeld, J.; Adams, G.; Roelofs, Y.; Ravensteyn, P. Blockchain-based Smart Contracts in Waste Management: A Silver Bullet? In Proceedings of the 31st Bled eConference: Digital Transformation: Meeting the Challenges, Bled, Slovenia, 20 June 2018.

83. Yu, Y.; Li, Y.; Tian, J.; Liu, J. Blockchain-Based Solutions to Security and Privacy Issues in the Internet of Things. IEEE Wirel. Commun. 2018, 25, 12-18. [CrossRef]

84. Saberi, S.; Kouhizadeh, M.; Sarkis, J.; Shen, L. Blockchain technology and its relationships to sustainable supply chain management. Int. J. Prod. Res. 2019, 57, 2117-2135. [CrossRef]

85. Dolgui, A.; Ivanov, D.; Potryasaev, S.; Sokolov, B.; Ivanova, M.; Werner, F. Blockchain-oriented dynamic modelling of smart contract design and execution in the supply chain. Int. J. Prod. Res. 2020, 58, 2184-2199. [CrossRef]

86. Rosen, M.A.; Kishawy, H.A. Sustainable Manufacturing and Design: Concepts, Practices and Needs. Sustainability 2012, 4, 154-174. [CrossRef]

87. Kulczycka, J.; Lelek, Ł.; Lewandowska, A.; Zarębska, J. Life Cycle Assessment of Municipal Solid Waste ManagementComparison of Results Using Different LCA Models. Pol. J. Environ. Stud. 2015, 24, 125-140. [CrossRef]

88. Sala, S.; Ciuffo, B.; Nijkamp, P. A systemic framework for sustainability assessment. Ecol. Econ. 2015, 119, 314-325. [CrossRef]

89. Esmaeilian, B.; Behdad, S.; Wang, B. The evolution and future of manufacturing: A review. J. Manuf. Syst. 2016, 39, 79-100. [CrossRef]

90. Esmaeilian, B.; Wang, B.; Lewis, K.; Duarte, F.; Ratti, C.; Behdad, S. The future of waste management in smart and sustainable cities: A review and concept paper. Waste Manag. 2018, 81, 177-195. [CrossRef] [PubMed]

91. Sarkis, J.; Cohen, M.J.; Dewick, P.; Schröder, P. A brave new world: Lessons from the COVID-19 pandemic for transitioning to sustainable supply and production. Resour. Conserv. Recycl. 2020, 159, 104894. [CrossRef] [PubMed]

92. Jabbour, A.B.L.D.S.; Jabbour, C.J.C.; Hingley, M.; Vilalta-Perdomo, E.L.; Ramsden, G.; Twigg, D. Sustainability of supply chains in the wake of the coronavirus (COVID-19/SARS-CoV-2) pandemic: Lessons and trends. Mod. Supply Chain Res. Appl. 2020, 2 117-122. [CrossRef]

93. Levin, J.; Riley, L.S.; Parrish, C.; English, D.; Ahn, S. The effect of portable pulsed xenon ultraviolet light after terminal cleaning on hospital-associated Clostridium difficile infection in a community hospital. Am. J. Infect. Control 2013, 41, 746-748. [CrossRef] [PubMed]

94. Kouhizadeh, M.; Sarkis, J. Blockchain Characteristics and Green Supply Chain Advancement. Adv. Logist. Oper. Manag. Sci. 2020, 93-109. [CrossRef] 